NBER WORKING PAPER SERIES

\title{
THE COST OF COMPLEXITY IN FEDERAL STUDENT AID: LESSONS FROM OPTIMAL TAX THEORY AND BEHAVIORAL ECONOMICS
}

\author{
Susan M. Dynarski \\ Judith E. Scott-Clayton \\ Working Paper 12227 \\ http://www.nber.org/papers/w12227

\section{NATIONAL BUREAU OF ECONOMIC RESEARCH} \\ 1050 Massachusetts Avenue \\ Cambridge, MA 02138 \\ May 2006
}

\begin{abstract}
Comments welcome: susan_dynarski@harvard.edu and jscottc@nber.org. We thank Sandy Baum, Sandy Jencks, Jeff Liebman, Sendhil Mullainathan and Sarah Turner for helpful discussions and comments on previous drafts. Scott-Clayton is grateful for funding from the National Science Foundation and the Harvard Multidisciplinary Program on Inequality and Social Policy. All errors are our own. The views expressed herein are those of the author(s) and do not necessarily reflect the views of the National Bureau of Economic Research.
\end{abstract}

(C2006 by Susan M. Dynarski and Judith E. Scott-Clayton. All rights reserved. Short sections of text, not to exceed two paragraphs, may be quoted without explicit permission provided that full credit, including () notice, is given to the source. 
The Cost of Complexity in Federal Student Aid: Lessons from Optimal Tax Theory and Behavioral Economics

Susan M. Dynarski and Judith E. Scott-Clayton

NBER Working Paper No. 12227

May 2006

JEL No. D0, H0, I0, J0

\begin{abstract}
The federal system for distributing student financial aid rivals the tax code in its complexity. Both have been a source of frustration and a focus of reform efforts for decades, yet the complexity of the student aid system has received comparatively little attention from economists. We describe the complexity of the aid system, and apply lessons from optimal tax theory and behavioral economics to show that complexity is a serious obstacle to both efficiency and equity in the distribution of student aid. We show that complexity disproportionately burdens those with the least ability to pay and undermines redistributive goals. We use detailed data from federal student aid applications to show that a radically simplified aid process can reproduce the current distribution of aid using a fraction of the information now collected.
\end{abstract}

Susan M. Dynarski

Harvard University

Kennedy School of Government

79 JFK Street

Cambridge, MA 02138

and NBER

susan dynarski@harvard.edu

Judith E. Scott-Clayton

Harvard University

Kennedy School of Government

79 JFK Street

Cambridge, MA 02138

jscottc@nber.org 


\section{Introduction}

The complexity of the federal tax code has been the focus of reform efforts for decades, and has received considerable attention in the economic literature. The federal system for distributing student financial aid is similarly convoluted, yet has received relatively little attention from economists. For the typical household, the aid application (the Free Application for Federal Student Aid, known as the FAFSA) is longer and more complicated than the federal tax return. The aid process is also highly uncertain, with definitive information about freshmanyear aid not revealed until the spring of the senior year in high school.

The consequences of complexity and uncertainty in aid extend beyond annoyance and frustration. The intent of financial aid is to reduce the cost of college, thereby encouraging college attendance. We argue that complexity disproportionately burdens those on the margin of college entry, thereby blunting the impact of aid on their schooling decisions. Uncertainty about aid similarly blunts its impact on behavior: high school students most sensitive to cost are unlikely to start down the path to college if they do not know it is affordable. For those on the margin of college entry, concrete information about aid simply arrives too late.

Evidence on the behavioral impact of aid supports our argument. While simple, easily communicated aid programs have been shown to have a robust impact on college entry and completion, we have little to no compelling evidence that the traditional forms of student aid (which require a FAFSA) increase schooling for their target populations. Complexity may be the culprit. Simply put, potential college students cannot respond to a price subsidy if they do not know it exists. As both the "sticker price" of college and aid for college have risen sharply, the net price of college has grown increasingly individualized, making it difficult for prospective students to estimate their own schooling costs. Most high school students overestimate the cost 
of attendance, but this confusion is of greater consequence for low-income students, who (unlike their upper-income counterparts) are pessimistic about their ability to pay for college (Avery and Kane, 2004).

We use well-known principles of optimal tax policy, as well as more recent insights from behavioral economics, to evaluate the costs of complexity in student financial aid. We demonstrate that provisions intended to precisely target aid produce regressive compliance costs. These costs rightly belong in our cost-benefit calculation when we consider the efficiency and equity of a given targeting provision. ${ }^{1}$ The costs of aid complexity fall heavily on low-income, non-white and non-English speaking youth, whose lagging educational levels are repeatedly cited as a justification for financial aid. Though from a rational perspective these compliance costs may seem small relative to the payoff of a college degree, the behavioral literature demonstrates conclusively that even seemingly minor complexities can have profound impacts upon the equity and efficiency of a policy.

We show not only that the costs of complexity in student aid are large, but also that the concomitant benefits are quite small. With student-level data from the 2003-04 National Postsecondary Student Aid Survey (NPSAS:04), we show that much of the complexity in the aid system fails to improve the targeting of aid. We find that the aid system imposes large costs in order to measure small differences in ability to pay. Nearly all of the variation in aid is generated by a handful of the more than 70 data items used in the aid formula. Parents' adjusted gross income (or, for tax non-filers, earnings from work), marital status, family size, and the number of family members in college explain over three-quarters of the variation in Pell Grant awards. With only a few more variables, we replicate 90 percent of the variation in Pell Grants for

\footnotetext{
${ }^{1}$ If this line of argument sounds eerily familiar, it is because it was made in the pages of this journal (Kaplow, 1996) in the context of the income tax system. The Final Report of the President's Advisory Panel on Federal Tax Reform repeatedly sounds the same theme.
} 
dependent students. Our radically simplified process throws out 80 percent of the financial items on the aid application. This aid application could fit on a single page. In fact, since the IRS $1040 \mathrm{EZ}$ already collects most of the key pieces of data that determine aid eligibility, a reasonable option would be to eliminate the FAFSA completely and run student aid through the tax system.

A simple aid program is an easily-communicated aid program. Simplification would allow personalized information about aid to be communicated to families early. Just as workers are annually sent projections of their Social Security benefits to help them plan for retirement, families could be sent estimates of their aid eligibility to help them plan for college. Under the current system, students do not get accurate information about student aid until late spring of senior year in high school. Early information about federal help for paying for college is critical for low-income families. If the goal of aid is to encourage college attendance, then the end of the final year of high school is simply too late for information about subsidies to arrive.

Our paper is emphatically not an argument against progressivity in aid. An aid system, like a tax system, can be both simple and progressive, and we conclude that reducing complexity in aid would be both efficient and equitable. The current aid system creates formidable barriers to college. A key lesson of our research is that we can dismantle these barriers if we are willing to tolerate minor imperfections in measuring ability to pay. This, we believe, is a worthwhile tradeoff. Reducing unnecessary complexity will allow aid to serve its intended goal: opening the doors of college to those who have the ability but not the means to further their education.

\section{Financial Aid Overview}

Two programs provide the bulk of federal aid to college students: the Pell Grant and the Stafford Loan. Both are distributed through the "need-determination" process, in which 
extensive data about a student's resources and expenses are used to estimate his "need" for aid. We will describe this process shortly.

During the 2004-05 academic year, $\$ 13$ billion in Pell Grants was delivered to five million students (expenditure data are from College Board, 2005). The grants averaged \$2,500 per recipient, with a maximum value of $\$ 4,050$. Pell Grants are highly progressive, flowing almost exclusively to families with incomes below $\$ 40,000$ (Stedman, 2003). During the same year, \$41 billion in low-interest loans was delivered to undergraduates through the Stafford Loan program. Since the loans are eventually paid back, the cost of the Stafford program is less than a quarter of this amount. Half of the Stafford loans distributed are need-based "subsidized" loans, for which the government pays the interest while the student is in college. The other half are "unsubsidized" Stafford loans, for which interest accrues during college. While the unsubsidized loans are provided regardless of need, students must go through the need-determination process to access them.

Dependent undergraduates can borrow $\$ 2,625$ for the first year of college, $\$ 3,500$ for the second year and $\$ 5,500$ in each of the next three years. ${ }^{2}$ Stafford loans do not require a credit check. Parents can borrow unsubsidized loans up to the cost of college (net of aid) through the federal PLUS program, which does require a credit check and for which interest accrues during college. Students whose parents do not pass the credit check are eligible for up to $\$ 5,000$ in unsubsidized Stafford loans over and above the usual annual caps (U.S. Dept. of Education, 2005b).

\footnotetext{
${ }^{2}$ Beginning in the 2007-08 academic year, loan limits will increase to $\$ 3,500$ for the first year and $\$ 4,500$ for the second year.
} 
The Free Application for Federal Student Aid (FAFSA) is required for all federal grants and loans. Most state aid and school scholarships also require the FAFSA. ${ }^{3}$ The FAFSA collects basic demographics (e.g., name, social security number, citizenship, date of birth, etc.) as well as detailed information about the student's and parents' income, assets, and expenditures. See Appendix for a copy of the 2006-07 FAFSA. Families cannot obtain an estimate of their federal aid eligibility without submitting a FAFSA. ${ }^{4}$ Prospective freshmen cannot file a FAFSA until January of their senior year of high school. The aid determination process is summarized in Figure 1.

\section{[FIGURE 1 ABOUT HERE]}

Once the FAFSA is submitted, the U.S. Department of Education computes the expected family contribution (EFC), an estimate of how much the family can pay out of pocket for college. "Need" is defined as the difference between the cost of attendance (e.g., tuition, fees, books, living expenses) and this family contribution. The EFC, but not any estimate of aid eligibility, is mailed to the applicant as well as the colleges to which she has applied. Using the EFC, colleges personalize a package of grants and loans for each student, which they then mail out in the form of award letters, typically in March and April. Only upon receiving these award letters do students know how much college will cost for the upcoming year.

In Table 1 we compare the FAFSA to the IRS 1040, 1040A and 1040EZ income tax forms. The FAFSA, at five pages and 128 questions, is lengthier than Form1040EZ (one page, with 37 questions) and Form 1040A (two pages, with 83 questions). It is comparable to Form 1040 (two pages, with 118 questions). With this comparison we do not mean to suggest that the

\footnotetext{
${ }^{3}$ Some colleges require an additional aid application, such as the College Board's PROFILE or a school-specific form.

${ }^{4}$ Some websites offer EFC calculators, which require the same data as the FAFSA. An enterprising student or parent could therefore calculate the EFC without completing a FAFSA. We would hazard that, for a family that is able to do this sort of sleuthing, federal financial aid is not a determinative factor in the college entry decision.
} 
U.S. tax system is a paradigm of simplicity. The statistics in Table 1 understate the complexity faced by taxpayers who must fill out additional worksheets and schedules in order to complete the questions listed on the 1040. But for the families targeted by need-based aid, complexity in the aid application rivals the complexity they experience in the income tax system. Most families eligible for the Pell file the shorter 1040A or 1040EZ; 86 percent of filing households with income below $\$ 50,000$ (and two-thirds of all households) use these simplified IRS forms. The contrast between Form 1040EZ and the FAFSA is especially striking. With a third of the FAFSA's questions and a fifth of its pages, the IRS captures the information needed to determine tax liability for the very population targeted by need-based aid.

\section{[TABLE 1 ABOUT HERE]}

Why is the FAFSA so long? In part, because the aid formula applies different "tax rates" to the student's and parents' resources, and so asks separate questions about each. ${ }^{5}$ But, as Table 1 shows, the FAFSA demands more detailed measures of financial resources than do the income tax forms. Thirty-four FAFSA questions probe for sources of income not shown on the W-2, compared to two on the 1040EZ, 12 on the 1040A and 19 on the 1040. Further, while none of the tax forms ask about assets, the FAFSA has six questions on this topic.

The IRS estimates it takes 16 hours to complete a 1040. The 1040A and 1040EZ are estimated to require 13 and eight hours, respectively. These are likely conservative estimates: Blumenthal and Slemrod (1992) conclude that the time required for tax compliance averages 27 hours per filing household, and is longer for low- and high-income households. The U.S. Department of Education improbably estimates that it takes one hour to complete the FAFSA.

\footnotetext{
${ }^{5}$ The highest tax rate on parental assets is about six percent for each year of college, while the student's assets can be taxed at 35 percent (this rate will fall to 20 percent as of the 2007-2008 academic year). The marginal tax rate on parental income ranges from 22 to 47 percent, while for student earnings the tax rate is zero below an earnings protection allowance and 50 percent above that allowance. See Dynarski (2004b) for a discussion of how the aid tax on assets varies by ownership and asset type.
} 
An obvious point, but one worth stating in this context, is that when a taxpayer has completed her 1040, she knows how much tax she owes. To this end, twenty-one of the questions on the 1040 are calculations or look-ups from tax tables. Completing the FAFSA yields no comparable information about aid eligibility. We will return to this point later in the paper. For now, we simply highlight the fact that, upon completing the FAFSA, the aid applicant is no more informed about her financial aid eligibility than she was when she began.

The complexity of the FAFSA not only creates costs, it obscures benefits. If the aid formula were transparent and communicated early, families would have clear incentives to fill out a long and intrusive form. But when families do not know the benefits of filling out the form, the costs weigh heavily. Simplifying the aid formula would not just shorten the FAFSA but allow families to determine their aid eligibility easily and early, when it can make a difference in their decisions.

\section{Insights from Optimal Tax Theory}

Complexity in the tax system arises from attempts to precisely measure taxpayers' ability to pay. ${ }^{6}$ Analogously, complexity in the need-based aid system arises from attempts to precisely measure ability to pay for college. As has been highlighted in the tax literature (Kaplow, 1990 and 1996), measuring income more accurately produces costs to society that are frequently ignored by policy-makers and analysts. Kaplow (1996) offers the following illustrative example. Consider two people with "true" income of $\$ 40,000$. Unless a deduction is allowed (say, for unusual health expenses) one person will have a reported income of $\$ 45,000$. Creating the deduction will allow for more accurate measurement of income, so the added complexity has a

\footnotetext{
${ }^{6}$ Complexity can also arise when policymakers "deviate from tax principles in order to subsidize certain activities and groups (Kaplow, 1996)." For example, the mortgage interest deduction and 401(k) are tax provisions intended to encourage homeownership and retirement saving, respectively.
} 
benefit: it prevents us from reducing one person's income below its socially optimal level. But there are also costs to this new provision:

1) efficiency loss as taxpayers alter their behavior so as to shield income under the deduction.

2) administrative costs for the government (or schools), which are ultimately paid by taxpayers in the form of higher taxes or reduced services.

3) compliance costs for taxpayers, such as time spent learning about the rules and formulas, record-keeping, and completing forms.

We will shortly provide detail on the extent of these complexity costs in the aid system, but for now let us speak of them in abstract terms.

These costs of complexity should be weighed against its benefits in determining whether a given aspect of the tax code (or aid system) enhances social welfare. Optimal tax theory shows that a transfer between two groups can be worthwhile if the socially-weighted gain in utility from those receiving the transfer outweighs the socially-weighted loss in utility of those paying for the transfer. The weights are critical: the transfer is a losing proposition if those giving and receiving weigh equally in the social welfare function, since the transfer then yields no social benefits but does produce efficiency, compliance and administrative costs. But a group that weighs heavily when we consider the benefits of the transfer also weighs heavily when we add up the costs of the transfer. Compliance costs that fall on a group with high weight in our social welfare function will disproportionately reduce social welfare. A key lesson is that any policy intended to redistribute income should be carefully crafted so that it does not create costs that outweigh its benefits.

An example will illustrate how compliance costs can have a regressive impact. Consider the Earned Income Tax Credit. Despite the large value of this credit, non-participation in the program is substantial and a perennial source of concern (Greenstein, 2005). Applying for the 
EITC may be quite daunting for the target population (Berube et al., 2002). Recently, H\&R Block and other tax preparers have found a market niche filing tax returns for low-income families eligible for the credit, and as a result seventy-five percent of EITC recipients now use a tax preparer (President's Advisory Panel on Federal Tax Reform, 2005). Both parties benefit the taxpayer gets a credit, and tax preparers take a cut in the form of a $\$ 100$ fee and (annualized) interest rates exceeding 200 percent charged on "refund loans" (Berube et al., 2002). A full accounting of the costs and benefits of the EITC would include these as compliance costs. Compliance costs clearly reduce the progressivity of the EITC, since part of the EITC leaks to tax preparers. A simplification that at first blush appears to reduce the progressivity of the EITC may prove progressive were it to reduce this leakage. We argue that the same holds in the aid system: a simplification that appears distributionally neutral may prove progressive in its incidence.

In some cases, costs can enhance efficiency because they fall on those seeking the transfer (Akerlof, 1978; Nichols and Zeckhauser, 1982). For example, requiring people to wait in long lines in order to receive welfare benefits may be efficient if those with the least need have the highest opportunity cost of their time. In this case, compliance costs help to screen out those who are not the intended targets of the transfer. But the inverse also holds: if compliance costs fall most heavily on the intended targets of the transfer, redistribution is less efficient. In the extreme, costs may drive the targeted group out of the program. ${ }^{7}$ For a variety of reasons that we detail below, compliance costs for student aid are likely highest for the poorest families, and may deflect some their intended target (low-income families) from applying.

\footnotetext{
${ }^{7}$ Indeed, there is evidence that complexity in the provision of social benefits reduces the take-up of transfers (Bitler, Currie, and Scholz, 2003; Brien and Swann, 1999; see literature review by Currie, 2004).
} 
We now describe the efficiency, administrative and compliance costs of complexity in the aid system.

\section{Efficiency Loss}

At the core of public finance is the principle that an efficient tax system taxes the broadest base at the lowest rate. Variation in tax rates (induced, for example, by excluding some goods from taxation) creates incentives and opportunities for gaming the system, such as shifting assets into untaxed financial vehicles. This has equity consequences, since these strategies are implemented only by those who have the resources to play the game - e.g., those who can hire advisers to find clever shelters for their income and assets. Tellingly, an industry of highly-paid aid advisers has emerged to guide families through the aid system.

\section{Administrative Costs}

The administrative costs of student aid accrue to both the government and colleges. The government's administrative costs (excluding the administration of federal direct student loans) are not strikingly high in comparison with the billions of dollars of aid distributed: an annual report from the Office for Student Financial Assistance estimated an operational/overhead cost of about $\$ 19$ per unduplicated grant/loan aid recipient in 2000, which would imply administrative costs of approximately $\$ 179$ million in 2004 (U.S. Dept. of Education, 2002c). ${ }^{8}$

The lion's share of administrative costs are borne by the colleges themselves, who are responsible for answering students' questions, verifying student information, and packaging and disbursing federal student aid. Financial aid administrators and support staff paid by the colleges

\footnotetext{
${ }^{8}$ In 2004 there were 9.4 million unduplicated aid recipients (U.S. Dept. of Education, 2005e, http://www.ed.gov/about/overview/budget/budget06/summary/edlite-section2d.html\#tables).
} 
are responsible for these tasks. To pay colleges' administrative costs, the Department of Education allocated to schools administrative allowances of $\$ 83.4$ million in $2005 .^{9}$ However, schools almost certainly incur costs far in excess of this allowance. Estimates of the annual cost of audits alone range from $\$ 132$ million (US Office of the Inspector General) to $\$ 432$ million (Advisory Committee on Student Financial Assistance, 2005). ${ }^{10}$ The lower bound of these estimates exceeds the entire administrative allowance for 2005. Note that since the colleges' costs are not a line item in the federal budget, they are likely to be overlooked when policymakers consider the costs and benefits of complexity in the aid process.

\section{Compliance Costs}

Compliance costs, which fall on applicants, are the focus of our analysis. Compliance costs include the time and resources required to learn about the system and its rules, collect all of the required documents, and fill out the form. Though low-income families likely have a relatively low opportunity cost of time, the length of time required to learn about and comply with any given provision of the aid process is higher for low-income families. In addition, some families face barriers (such as language) that additional time does little to diminish.

\footnotetext{
${ }^{9}$ This is calculated from data at http://www.ed.gov/about/overview/budget/budget06/summary/edlitesection2d.html\#tables. Schools can allocate to administrative costs five percent of their funds for Supplemental Educational Opportunity Grants, work-study, and Perkins Loans; these aid sources totaled \$3.3 billion in 2005. Schools are also allocated five dollars per Pell Grant recipient, of which there were 5.33 million in 2005.

${ }^{10}$ The OIG and ACSFA estimates are contained (respectively) in US Department of Education (2002a) and Advisory Committee on Student Financial Assistance (2005).
} 
Low-income families have little prior experience with the aid system, since the parents are unlikely to have gone to college and applied for aid themselves. Half of low-income high school seniors do not have a parent who ever attended college. ${ }^{11}$ Their classmates and siblings are also relatively unlikely to attend college. This lack of college-going peers and relatives blocks a channel that could communicate information about need-based aid to the target population. Liebman (1998) concludes that peers play a crucial role in informally transmitting information about the EITC, a complicated tax program that encourages work by partially matching the wages of low-income parents. ${ }^{12}$ A non-working, low-income mother may observe the improving financial position of neighbors who have entered the workforce and (unknown to her) received the EITC. Even if she does not understand the structure of the EITC's incentives, she may respond as if she did, and enter the workforce. Since 80 percent of families with incomes between 100 and 150 percent of the poverty line receive the EITC, this is a plausible scenario; a poor person is likely to know someone benefiting from the EITC. By contrast, just $34 \%$ of low-income black youth and 33\% of low-income Hispanics have even attempted college, severely limiting the informal transmission of information about college costs within these populations. $^{13}$

\footnotetext{
${ }^{11}$ Authors' calculations using data from the National Educational Longitudinal Survey of 1988, comparing families with income below $\$ 25,000$ to those with income above $\$ 50,000$.

${ }^{12}$ Bertrand, Luttmer, and Mullainathan (2000) and Duflo and Saez (2001) show that social networks have a strong influence on welfare participation and saving behavior, respectively.

${ }^{13}$ Authors' calculations using the National Longitudinal Survey of Youth, 1997. We measure college entry by 1999 for those who were 16 to 17 years old in 1997, which is when family income is measured. Low income is defined as having family income below \$20,000 in 1997.
} 
People can learn about complicated programs not only from observing peers' transactions but also through their own repeated transactions. Liebman and Zeckhauser (2005) conclude that when faced with complicated price schedules (such as those for cell phone contracts) people may respond not to marginal prices but "average" prices gleaned from past experience. In the case of college, interactions with the aid system for a given family are infrequent, so opportunities for backing out average prices are rare.

Language is another barrier, with 13 percent of low-income students primarily speaking a language other than English at home, double the rate of families with above-median incomes. ${ }^{14}$ Even the basic step of locating financial records is an obstacle for poor students, due to higher mobility rates and family dysfunctions such as divorce and separation of children from parents. Low-income families are substantially less likely to have access to the internet at home, a handicap in a system that relies heavily upon the web for the dissemination of information and is moving towards an exclusively on-line application system. In 2003, over two-thirds of children from families with incomes below $\$ 25,000$ had no access to the internet at home, compared to 12 percent of families with incomes above $\$ 50,000 .{ }^{15}$ Families may be reluctant to bring financial documents to a school or a library in order to enter these data into a public computer.

In sum, poorer families are likely to face greater costs of learning about the aid system, collecting the required documents, and completing the aid form. Since compliance costs correlate with poverty, and the poor weigh heavily in our calculations of social welfare, we should strive to minimize their compliance costs. Consider the case in which we seek to measure ability to pay for college more accurately by asking questions about untaxed income, such as welfare benefits and disability benefits. Such questions account for much of the complexity in

\footnotetext{
${ }^{14}$ Ibid.

${ }^{15}$ Source: Authors' computations using published tables from the 2003 Computer and Internet Supplement to the Current Population Survey, http://www.census.gov/prod/2005pubs/p23-208.pdf.
} 
the aid application. These questions are asked in order to withhold aid from families that can pay more out of pocket than implied by a less precise measure of income. The benefit of this added complexity is that money can be now channeled toward more optimal uses: more "needy" aid recipients, other government programs, or lower tax rates. If the source of income is quite rare, then only a small amount of money will be freed up in this way, yet every aid applicant must still read through the additional questions and instructions in order to determine whether any of her income falls into the relevant category. In this case, compliance costs could easily outweigh the freed-up funds produced by the additional questions.

\section{Insights from Behavioral Economics}

We have made the case that the cost of compliance in the aid system is substantial, especially for low-income families, and that this complexity blunts the impact of the subsidies on schooling decisions. However, a valid rejoinder to this argument is that the financial returns to a college education dwarf any reasonable estimate of the costs of applying for aid. Thus, if people behave rationally, anyone who is deterred from going to college by such relatively small compliance costs must have an unusually low expected return to college.

A key insight of behavioral economics is that people systematically do not behave rationally, even in matters where we might most expect calculating rationality. Indeed, individuals deviate from rationality in highly predictable ways that tend to shock only economists. In this section, we provide a brief overview of insights that behavioral economics can offer in the realm of student aid and college attendance. 


\section{Time Inconsistency}

People are poor at committing to behaviors that require present sacrifice in pursuit of future returns (O’Donoghue and Rabin, 1999). This characterizes a broad range of behaviors, including saving for retirement, exercise, and schooling. People may plan to get up early to exercise, but hit the snooze button when the alarm goes off. They may plan to save for retirement, but never enroll in their employer's 401(k). They may plan to go to college, but fail to fill out their FAFSA or register for the SAT. While they may firmly believe that saving or exercise or college is the right choice, when the time comes to make the required sacrifice, commitment falters. These are examples of what economists refer to as time-inconsistent preferences.

By its nature, college is an investment: upfront sacrifices are required (tuition, forgone earnings, studying) in order to obtain back-loaded benefits (better job, higher earnings, higher social status). Applying for aid is part of the cost of college, requiring a current sacrifice in order to yield a future return. Given that adults are guilty of procrastination and avoidance in quite high-stakes investments (Thaler, 1994), we would not expect all teenagers who would benefit from aid to apply.

\section{Loss Aversion}

Nobel Laureates Daniel Kahneman and Amos Tversky (2000) show that people are loss averse: they avoid worthwhile bets because "losses weigh more heavily than gains." That is, a dollar lost decreases utility more than a dollar gained increases it. In lab experiments and in realworld settings, people "underweight outcomes that are merely probable in comparison with outcomes that are obtained with certainty (Kahneman and Tversky, 2000)." When it is the gains 
that are probable and the losses that are certain, this will lead to risk aversion and avoidance of even "good bets." Certain costs and probable gains characterize college. Students must apply for aid, give up earnings, pay tuition, and study. These are certain outlays. By contrast, students cannot know with certainty how well their investment will pay off. While, on average, college is a good bet, there is enormous variance in the earnings of college graduates. For some, college will not pay off, and this possibility may weigh heavily in schooling decisions due to loss aversion.

\section{Default Behavior}

Economists and psychologists have found that individuals' decisions are strongly influenced by their "default" course of action (Samuelson and Zeckhauser, 1988). An influential study examined retirement saving at a large financial firm (Madrian and Shea, 2001). At this

firm, 401(k) participation required that new employees check a box on a form; the consequence of not checking that box was not participating in the 401(k). That is, the default option was nonparticipation. Despite the low transaction costs of enrollment and strong financial incentives (tax advantages plus an employer match of savings), participation rates were low. The company made a minor change: non-participation now required that the new employee check a box on a form and so participation was the default option. This small change in program design had a profound effect on behavior, increasing participation by 50 percentage points.

Seemingly minor obstacles put low-income youth off the path to college, much as adults are put off the path to saving by bureaucratic details. A study of high school seniors in Boston found that few low-income youth "decide" against college. Rather, they miss a key deadline, or incorrectly fill out a form, or fail to take a required class, and thereby fall off the path to college 
(Avery and Kane, 2004). For upper-income teenagers, the affirmative actions of their parents and schools establish college entry as the "default" path. Their high schools guide them through the multiple steps and deadlines of the college and financial aid process. Schools provide SAT preparation on site, schedule exams for students, organize the writing of recommendations, and remind students repeatedly about relevant deadlines. Informal guidance and support is also provided by their college-educated relatives and neighbors, who act as de facto guidance counselors.

By contrast, due to their comparatively weak institutional and social supports, the default option for low-income students is to not go to college. Navigating the maze of college and aid application requires both formal and informal support. Lower-income schools receive fewer visits from college representatives and have fewer guidance counselors per student. ${ }^{16}$ Parents and siblings are not likely have gone to college, and so cannot compensate for this lack of institutional support.

\section{Identity Salience}

A program may discourage participation through the self-identification it triggers in people. The food stamp application process, for example, "cues negative identities and can induce guilt and alienation," thereby discouraging take-up (Bertrand, Mullainathan, and Shafir, 2004). The FAFSA is rich with negative cues relating to poverty and criminal activity. The FAFSA asks "Have you ever been convicted of possessing or selling illegal drugs? If you have, answer 'Yes,' complete and submit this application, and we will send you a worksheet in the mail for you to determine if your conviction affects your eligibility for aid." The final step in

\footnotetext{
${ }^{16}$ Data on college representatives comes from NELS:88-2000, 1992 school survey. Counselors comes from The Condition of Education 2000, Indicator 28, see also Indicator 27.
} 
submitting a FAFSA is the signing of a statement which concludes with "If you purposely give false or misleading information, you may be fined $\$ 20,000$, sent to prison, or both.” The full signing statement is nearly five times longer than that on IRS Form 1040. Multiple questions about welfare payments repeatedly remind low-income students about their poverty, while openended questions that require the calculation of net worth or income (applicants are asked about "money received, or paid on your behalf (e.g. bills), not reported elsewhere on this form") could generate anxiety among even middle-class applicants.

\section{Evidence on the Impact of Student Aid}

There is plenty of evidence that student financial aid can have a large impact on behavior. Data from the National Longitudinal Survey of Youth show that the Social Security Student Benefit program substantially increased college enrollment rates among eligible youth (Dynarski, 2003). Under this program, children of Social Security beneficiaries continued to get their benefits past their usual expiration at age 18, as long as they enrolled in college. The compliance costs were minimal. The Social Security Administration sent a letter to child beneficiaries shortly before their $18^{\text {th }}$ birthday, asking if they intended to go to college. If they replied in the affirmative, checks continued to arrive. Renewal required confirmation of enrollment from the college registrar. The program provided early information, in that beneficiary families were familiar with the provision. Families knew the exact amount of the benefit, since they were already receiving it.

Another simple program, Georgia's HOPE Scholarship, requires only that high school students maintain a 3.0 GPA in high school in order to have their tuition and fees paid at any public college in Georgia. High schools proactively send transcript data to the state in order to 
identify scholarship winners. For most students, the HOPE application consists of a half-page of basic biographical information. High school students are knowledgeable about the program. More than seventy percent of Georgia high-school freshmen surveyed were able to name the program without prompting. Fifty-nine percent, when asked to list some requirements of HOPE, volunteered that a high school GPA of 3.0 is necessary (Henry, et al, 1998). The program substantially increased college entry in Georgia (Dynarski, 2000), as well as the share of young people completing a college degree (Dynarski, 2005). Research on similar state programs has produced similar findings (Kane, 2003; Dynarski, 2004a and 2005).

By contrast, there is little to no persuasive evidence that the Pell grant program affects college enrollment decisions of young people. ${ }^{17}$ A plausible explanation is that the application process screens out students teetering on the margin of college entry. A prospective student who is able to deduce her aid eligibility, apply to college without knowing what resources will be available to pay for it, and successfully complete the FAFSA almost by definition reveals herself as firmly committed to attending college.

\section{Simplifying the aid system}

We have argued that the costs of complexity in the federal student aid process are substantial. We now measure the benefits of this complexity. How much does complexity improve targeting in the aid system? We are especially interested in the "low-hanging fruit" -

\footnotetext{
${ }^{17}$ An early study by Hansen (1983) examined enrollment rates before and after implementation of the Pell Grant program. Hansen found that while enrollment rates of all income groups increased during the 1970s, enrollment among low-income students did not increase disproportionately. Kane (1995) utilizes more years of data and limits the sample to women, whose enrollment patterns were less disrupted by the Vietnam War but is also unable to find an effect. Seftor and Turner (2002) find a small effect of Pell Grants on college enrollment for older, independent students. Bettinger (2004) finds suggestive evidence that Pell Grant size affects college completion, but notes his results are very sensitive.
} 
that is, identifying complexity that creates barriers to applicants while providing little payback in the form of improved targeting.

Using data from the nationally representative 2003-04 National Postsecondary Student Aid Survey (NPSAS:04), we examine the relationship between federal aid received and information in the FAFSA. We focus on Pell Grants, since they are the most expensive component of federal need-based aid, but we also present results for subsidized Stafford loan eligibility and for the EFC (as a proxy for all other need-based aid eligibility). Our sample consists of 15,603 undergraduates who attended college full-time in 2003-04 and who applied for federal aid (see Appendix for details). ${ }^{18}$ To simplify the analysis and exposition, all of our simulations are limited to dependent students. ${ }^{19}$ We see no conceptual barriers to extending the simulations to independent students, for whom there is a distinct but similar aid formula. Our confidence is bolstered by a Congressional Research Service analysis that concludes that the same FAFSA items explain most of the variation in the EFC for independent and dependent students (Stoll and Stedman, 2004).

We first use the NPSAS data to replicate the current distribution of aid. We calculate aid using the federal financial aid formula (described in Appendix) and compare these calculated aid amounts with their true values, which are given in the NPSAS. Our calculations of Pell Grants and EFCs are extremely close to their true values. Regressing the actual against the predicted values yields an $\mathrm{R}^{2}$ of 1.00 for the EFC and 0.997 for the Pell. For Stafford loans, it is not possible to validate our estimate in this way: NPSAS contains data about loan take-up but not

\footnotetext{
${ }^{18}$ We exclude the six percent of observations for whom we cannot replicate the Pell or EFC within $\$ 1,000$, even using all of the data and the exact federal aid formula. For half of these cases, we calculate a Pell grant of at least $\$ 1,000$, while the actual grant is zero. These are likely cases in which an applicant was audited and failed to provide documentation, or reflect adjustments made by aid administrators, who can exercise professional judgment in distributing aid.

${ }^{19}$ With rare exceptions (e.g., parental desertion or death) students are considered dependent if they are under the age of 24, unmarried, and have no children. Of full-time students attending a single institution all year who applied for federal aid, 62 percent were classified as dependent.
} 
loan eligibility, and many people do not take-up the full loan for which they are eligible (for the Pell Grant, eligibility and take-up are essentially identical). However, our results suggest that we are accurately calculating eligibility. Our prediction of Stafford eligibility is within one dollar of the actual loan amount for 70 percent of borrowers.

To measure the influence of the various data elements on aid, we sequentially exclude data items from the aid formula and recalculate aid, and then compare the new estimates to the baseline values described above. ${ }^{20}$ Mechanically, this is achieved by setting the value of the excluded items to zero. ${ }^{21}$ We measure the predictive power of these simulations with the $\mathrm{R}^{2}$ from regressions of the baseline aid values against their simulated values under simplification.

The $\mathrm{R}^{2}$ communicates the proportion of the variation in aid that can be attributed to each set of variables, but it does not tell us who wins and who loses. We therefore plot gains and losses against families' financial resources. As our measure of financial resources, we will primarily use the aid system's current summary statistic for a family's ability to pay for college, the expected family contribution (EFC). If our simulations reproduce the current distribution of aid across the EFC, then we have successfully reproduced the current system's distributional priorities. We will also use adjusted gross income, a more familiar metric for financial resources, for some of our graphs.

\footnotetext{
${ }^{20} \mathrm{We}$ are not the first to estimate the predictive power of individual FAFSA items on student aid. Kane (1995) notes that most of the variation in Pell Grants can be explained using just a few variables. Stoll and Stedman (2004) use student-level FAFSA data (from the 1999-2000 NPSAS) to simulate the effect on the EFC of excluding items from the aid calculation.

${ }^{21}$ We have also tested setting excluded values to their means or medians, with substantively similar results. For state of residence and elder parent's age, which are excluded from some simulations, a value of zero is not meaningful, so we assign to all applicants the default values that the aid formula imputes when these items are missing from a FAFSA.
} 
Simulation A: Distribute Aid Using Income, Assets and Family Structure

We start with Simulation A, in which we throw out all of the data used in the aid calculation except for adjusted gross income of the parents (or, for non-filers, earnings), student earnings, parents' and student's assets, parents' marital status, family size and number of family members in college. This approach discards parents' and student's taxes paid, the types of income tax forms filed and the required worksheets (reproduced in Appendix) that elicit information about transfer income (such as the EITC, welfare, and Social Security) and other income (child support). These worksheets account for 45 of the 70 financial questions used in the calculation of aid.

\section{[TABLE 2 ABOUT HERE]}

The extensive data we drop in this simulation explain only ten percent of the variation in aid (Column (1), Table 2). With the few variables we include, we explain 90 percent of the variation in the Pell Grant and 93 percent of the variation in the EFC, and 79 percent of the variation in subsidized Stafford loan eligibility. Using only the items in Simulation A would cut the number of financial questions on the FAFSA by more than 80 percent, while changing the Pell Grant by less than $\$ 500$ for 88 percent of the sample.

The worksheet data appear particularly uninformative. Discarding only the worksheets (results not shown) changes the Pell Grants by less than $\$ 100$ for 82 percent of students and by less than $\$ 500$ for 91 percent of students. Worksheet C, which contains four questions on education tax credits, child support, and work-study earnings, is especially egregious, explaining 0.1 percent of the variation in the $\mathrm{EFC}, 0.7$ percent of the variation in loan eligibility, and 0.8 percent of the variation in the Pell Grant. ${ }^{22}$

\footnotetext{
${ }^{22}$ Unfortunately, we cannot say which of the individual worksheet questions have predictive power and which do not. The worksheets are not submitted by applicants; their summary calculations are entered on the FAFSA.
} 
The parent and student worksheets likely have so little explanatory power for two reasons. First, many of the topics queried on these worksheets are relevant to few families (e.g., living stipends for the military and clergy, foreign income). Second, many of the questions are only relevant for families near the top or bottom of the income distribution (e.g., IRA rollovers and welfare benefits). Based on their AGI, these families either qualify for no aid or the maximum of aid, so their aid eligibility is insensitive to the worksheet items. As a result, the worksheets don't affect aid eligibility much, despite the substantial compliance costs they create.

Plotting simulated Pell Grant eligibility against true EFC shows that this approach produces a distribution almost identical to the current one (see Figure 2.1, in which each EFC bracket represents five percent of the sample). Student loan eligibility drops in the upper EFC ranges (Figure 2.2), largely because this simulation excludes parents' tax liability, which currently decreases the amount that families are expected to pay out of pocket. Table 3 provides rough estimates of the revenue implications of each approach; these estimates reflect the projected change in aid for our population of dependent undergraduates. Simulation A increases Pell costs by just $\$ 9$ per student, or less than one percent. Loan offers drop by about ten percent.

\section{[FIGURES 2.1 AND 2.2 ABOUT HERE]}

\section{[TABLE 3 ABOUT HERE]}

\section{Simulation B: Distribute Aid Using Income and Family Structure, Dropping Assets}

We next discard parents' and student's assets from the simulation. The "taxation" of assets by the aid formula has been roundly criticized by economists. Edlin (1993) and others have argued that the taxation of assets by the aid formula creates horizontal inequities. Identical families with identical lifetime earnings can be treated very differently by the aid system, with 
aid reduced for the family that has sacrificed consumption in order to save for college. A rejoinder is that assets serve as a summary statistic for lifetime earnings, which are imperfectly captured by current earnings. An alternative approach to measuring lifetime earnings, also suggested by Edlin, is to estimate ability to pay using multiple years of earnings. We consider this a sensible option worth consideration.

In practical terms, assets have little impact on the calculation of federal aid. Moving from Simulation A to Simulation B has relatively little effect on our predictive power. We still explain 86 percent of the variation in the Pell, 76 percent of the variation in the subsidized Stafford loan and 84 percent of the variation in the EFC. Our simulated Pell falls within $\$ 500$ of true Pell for 86 percent of applicants. The Pell is essentially unchanged at low levels of the EFC, and rises slightly at the middle of the EFC distribution (Figure 3.2). Loan eligibility drops in the middle and upper ranges of the EFC (Figure 3.2). The overall effect is an eight percent increase in Pell Grants and a six percent drop in subsidized Stafford loans (Table 3).

To isolate the impact of assets on the current distribution of aid, we also calculated changes in the Pell and subsidized Stafford loan that would be induced by excluding only assets from the current formula. ${ }^{23}$ Figures 4.1 and 4.2 plot the changes. Since ignoring assets can only increase need, this approach increases aid eligibility across the board, but by very small amounts. Pell Grants rise imperceptibly in the middle of the EFC distribution.

Ignoring assets does not substantially alter the distribution of aid (in this static simulation) because the bulk of household assets are already excluded from the aid calculation. Retirement funds and home equity are ignored by the federal aid formula, and this is where most

${ }^{23}$. That is, we restore all of the variables we had previously excluded, except for parents' and student's assets. 
households hold their assets. ${ }^{24}$ Other assets are assessed only if they fall above a threshold that rises with the age of the oldest parent; in 2003-04, the threshold was $\$ 54,500$ for a two-parent family (or $\$ 26,200$ for a single-parent family) in which the older parent was 55 . To demonstrate that assets are determinative of federal aid for only a small number of families, we added $\$ 100$ to every family's financial assets and recalculated aid eligibility. For 99 and 85 percent of the sample, respectively, the Pell Grant and EFC were unchanged.

This may be a case, however, in which the dynamic effect of aid simplification differs substantially from its static effect. Families with substantial assets who do not currently bother applying for aid may apply if assets are completely excluded from the aid formula. The revenue risks of such a behavioral response can be estimated by comparing the assets of current FAFSA applicants to the assets of all households with children in college, which we plan to do in future work. The current analysis, at least, offers no support for the view that eliminating the aid tax would substantially undermine the progressivity of federal aid. .

[FIGURES 3.1 AND 3.2 ABOUT HERE]

[FIGURES 4.1 AND 4.2 ABOUT HERE]

Simulation C: Distribute Aid Using Income and Family Structure, Dropping All Assets and Students' Earnings

We next exclude student earnings from the calculation of aid, reducing to four the required items: parents' income, parents' marital status, family size, and number of family members in college. These items, captured by six questions on the FAFSA, explain 77 percent of the variation in the Pell Grant, 76 percent of the variation in eligibility for the subsidized Stafford

\footnotetext{
${ }^{24}$ All asset information is currently excluded from the EFC calculation for families that qualify for the "simplified needs test" or "automatic zero EFC," both of which we will discuss later in the paper.
} 
loan and 83 percent of the variation in the EFC. In this simulation, Pell Grant eligibility rises toward the middle of the EFC distribution (Figure 5.1). This is the most costly of the approaches, with average Pell Grants increasing by $\$ 268$ per applicant ( 25 percent) relative to baseline. Subsidized loan volume drops slightly from its current level.

The aid system's treatment of student earnings is deeply flawed, from both an equity and an efficiency standpoint. The aid formula taxes student earnings (over an income protection allowance of $\$ 2,550$ ) at a rate of fifty percent. ${ }^{25}$ This is a very high tax on students' work effort, and may serve to discourage work. Further, the tax falls more heavily on low-income students, since both work effort and earnings drop as parental income rises. While 73 percent of students from lower-income families have positive earnings, the figure is 62 percent for students from upper-income families. ${ }^{26}$ Median student earnings are $\$ 2,730$ for the lower-income group, as compared to $\$ 2,231$ for the upper income group.

To isolate the relationship between student earnings and aid, we simulated an approach that keeps the current formula intact except for the tax on student earnings. Relative to the current system, the distributional impact of this change is to increase average Pell Grants by about $\$ 500$ for those from families with incomes between $\$ 15,000$ and $\$ 45,000$, and increase eligibility for subsidized loans by a couple of hundred dollars in the upper income ranges. Though this might be a desirable change, it is clearly expensive. An approach that would keep costs at their current level, reduce compliance costs, and reward students for working would be to assume that all students contribute a lump sum to their schooling expenses. This does not tax students' work effort on the margin, yet has them contributing to schooling costs.

\footnotetext{
${ }^{25}$ In 2007-2008, the amount will rise to $\$ 3,000$. Students also receive allowances for federal taxes paid and an estimate of state taxes paid. If parents' total allowances exceed parents' income, the excess parents' allowance is used to protect more of the student's income.

${ }^{26}$ We divide families at the rough median of household income, $\$ 50,000$.
} 
We have tested this approach with a variant of Simulation C. We predict aid using parents' income, parents' marital status, family size, and number of family members in college , but additionally require of each student (except for those with very low family incomes) a lumpsum contribution to schooling costs of $\$ 1,000$. This approach keeps Pell Grant spending at its current level and reduces the volume of subsidized loans offered by 7 percent (see Table 3).

In Figure 6.1, we plot the associated changes in Pell Grant eligibility against parents' adjusted gross income. The results are highly progressive, shifting grants toward those whose parents earn below $\$ 25,000$. By contrast, if we plot the changes in Pell eligibility against current EFC (Figure 6.2), the reform looks regressive. This is because the current EFC formula counts some families as "richer" simply because their college students work more hours. We argue that student earnings are almost completely a measure of effort, and thus should be excluded from the calculation of ability to pay.

[FIGURES 5.1 AND 5.2 ABOUT HERE]

[FIGURES 6.1 AND 6.2 ABOUT HERE]

\section{Simulation D: Distribute Aid Using Only Income}

Exhibit 1 describes a radically simplified aid system, encompassing Pell Grants, subsidized loans, and unsubsidized loans. In this model, which we have mocked up to fit on a postcard, Pell Grant eligibility is based solely on parents' adjusted gross income. Subsidized loan eligibility is a flat $\$ 5,000$ for all families earning below $\$ 75,000$, without regard to cost of attendance or other student resources. Unsubsidized loans could be made available to all families up to the cost of attendance (with rules similar to the rules for existing parent PLUS loans). 


\section{[EXHIBIT 1 ABOUT HERE]}

This very simple approach explains 75 percent of the variation in current Pell Grants. As was true in the previous simulation, when we also excluded student earnings, this approach appears regressive when plotted against EFC but progressive when plotted against AGI (see Figures 7.1 and 7.2). On average, Pell Grants increase by $\$ 53$ per student, resulting in a cost increase of $\$ 165$ million (5 percent) for dependent undergraduates. Subsidized loan offers increase by an average of $\$ 794$, for a total increase of $\$ 2.4$ billion (30 percent) in loan offers. It should be noted, however, that as of July 1, 2007 the loan maxima will increase. Relative to the new caps, this simulation raises loan offers by $\$ 1.4$ billion (17 percent). It is also worth reiterating that these loan offers cost taxpayers only a fraction of their face value, since many students (30 percent) do not even take up their loans and most of the face value of the loan is repaid with interest.

\section{[FIGURES 7.1 AND 7.2 ABOUT HERE]}

This radically simplified system dismantles many of the behavioral obstacles discussed earlier. The design is simple enough that families can predict their eligibility for aid well in advance of their child's high school graduation. It is easy to explain and easy to remember. It could be proactively mailed to families. In addition, with such limited data requirements, the entire aid processing system could be rerouted through the tax system, which already collects the sole determinant of eligibility, adjusted gross income. ${ }^{27}$

\footnotetext{
${ }^{27} \mathrm{We}$ can treat non-filers the same way the current aid system does, using earnings rather than AGI to assign aid.
} 


\section{Barriers to Aid Simplification}

Each of the approaches to simplification that we have discussed produces winners and losers. Losers are inevitable when simplification is constrained by revenue neutrality, as noted by the Final Report of the President's Commission on Tax Reform. The only way to simplify and keep everybody whole is to increase spending.

Even producing winners can cause political problems. Winners are those whose estimated ability to pay drops when we shift to a simpler measurement of income. By implication, many families who do not currently "deserve" aid will get it under a simplified system. Some will perceive the receipt of aid by such students as fraud, or evasion, or a policy failure. We perceive it as a cost of simplification, outweighed by the benefits it confers on the vast majority of students but especially upon the student teetering on the margin of entering college.

While the political barriers to aid simplification are substantial, the bureaucratic barriers may be even greater. Over the years, Congress has passed several provisions aimed at simplifying the aid formula. In 1986, Congress mandated an "automatic zero" EFC for families with taxable income below $\$ 15,000$ who are also eligible to file an IRS Form 1040A or 1040EZ. These applicants can potentially skip more than 50 of the over 70 financial questions on the FAFSA. Congress also mandated a "simplified needs test" for families earning less than $\$ 50,000$ who are eligible to file the 1040A or 1040EZ; for these families, asset information can be disregarded.

While laudable in intent, these efforts have been ineffectual. As implemented, these simplifications have had virtually no impact on the aid system as it is experienced by students and parents. In our sample, just half of applicants from families with income between $\$ 5,000$ and $\$ 15,000$ had their applications processed using the automatic-zero EFC or simplified needs 
test. Even among the applicants whose FAFSAs were flagged as having received this simplified treatment, the evidence indicates that the student's application experience was not simplified. Among those who had their FAFSA processed using the simplified needs test, and who were eligible to skip the asset questions, 48 percent provided asset information. Among those who had their application processed under the automatic-zero EFC formula, 90 percent had responded to questions that they were not required to answer. For example, 63 percent had non-zero amounts reported in Worksheet $\mathrm{A}$ and 30 percent reported non-zero assets.

In effect, simplification has only made things easier for the computer that processes aid applications. Simplifications are not communicated to students and their families; they are never mentioned on the paper FAFSA, used by about half of dependent, undergraduate applicants with incomes below $\$ 50,000 .^{28}$ Even the online FAFSA only offers the option to skip the relevant questions mid-application, and then warns that some schools may require that the questions be answered. This phrasing will frighten many students into filling in the complete application.

An additional barrier to simplification has been the states, who run their own aid programs. Thirty-two states have rejected the federal simplifications, requiring the full FAFSA data from applicants; in these cases, applicants using the web FAFSA never see a window that allows them to skip questions. This imposes large compliance costs for all applicants in order to distribute small amounts of aid to a few students. In half of the states, need-based grants average less than \$200 per undergraduate (National Association of State Student Gant and Aid Programs, 2005). By comparison, Pell Grants average $\$ 1,100$ in our sample of dependent undergraduates.

${ }^{28}$ Authors' calculations from NPSAS:04. 


\section{Conclusion}

There is no doubt that the need-based aid system gets grants and loans to many lowincome families who would be worse off without it. There is little to no evidence that this aid has the behavioral effect it is intended to have: getting more young people into college. In this paper, we have proposed both modest and radical simplifications to the aid system that would preserve its progressive nature while enhancing its positive impact on schooling decisions.

Our contribution is to use the perspectives of optimal tax theory and behavioral economics to explore the costs of complexity in financial aid for college. Optimal tax theory reminds us that compliance costs rightly belong in our cost-benefit calculation when we consider the efficiency and equity of a given targeting provision. We find that provisions intended to precisely target aid to those with the lowest ability to pay unintentionally produce regressive compliance costs. Behavioral economics suggests that minor differences in program design can have profound impacts upon the equity and efficiency of student aid. We identify multiple aspects of the aid system that behavioral economics suggest will blunt its impact upon schooling decisions.

The basics of need-determination have changed little since they were laid out fifty years ago. At a College Board conference in 1953, John Monro, then-dean of admissions at Harvard College, described to his colleagues at other elite colleges the formula he had been using to distribute aid to Harvard admits. The assembled college administrators were eager to establish a common formula for assigning aid, so that they could quash the competitive bidding for the best students that that had recently developed. Within a year, a common aid application was in use (the Parents' Confidential Statement) and the new College Scholarship Service (CSS) had been established by 94 charter members (Duffy and Goldberg, 1998; Wilkinson, 2005). 
Then, as now, Harvard and other elite schools sought exhaustive measures of wealth and income to tailor their scholarships. ${ }^{29}$ Today's FAFSA and aid formula reflect this peculiar history, providing extremely fine measures of ability to pay at levels of income that far exceed the effective cutoffs for federal aid. While these distinctions are critical at institutions that provide need-based grants to families with incomes well above \$100,000 (Dynarski, 2004b), we have shown such fine measures are irrelevant for the distribution of Pell Grants and Stafford Loans.

The U.S. system for subsidizing college students buries information about the affordability of college within a thicket of paperwork. It delays sharing information with prospective college students about the affordability of college until it is too late. As a result, the impact of federal student aid remains far below its potential.

\footnotetext{
${ }^{29}$ Until 1973, the aid application asked about make and model of the family car (Wilkinson, 2005).
} 


\section{References}

Advisory Committee on Student Financial Assistance. "The Student Aid Gauntlet: Making Access to College Simple and Certain: Final Report of the Special Study of Simplification of Need Analysis and Application for Title IV Aid." Washington, D.C.: Advisory Committee on Student Financial Assistance (January 23, 2005). URL: http://www.ed.gov/about/bdscomm/list/acsfa/edlite-gauntlet.html

Akerlof, George A. "The Economics of 'Tagging' as Applied to the Optimal Income Tax, Welfare Programs, and Manpower Planning." American Economic Review 68, no. 1 (March 1978): 8-19.

Avery, Christopher and Thomas J. Kane. "Student Perceptions of College Opportunities: The Boston COACH Program." In College Choices: The Economics of Where to Go, When to Go, and How To Pay for It, edited by Caroline Hoxby, 355-394. Chicago: University of Chicago Press, 2004.

Bertrand, Marianne, Erzo F. P. Luttmer, and Sendhil Mullainathan. "Network Effects and Welfare Cultures.” Quarterly Journal of Economics 115, no. 3 (August 2000): 1019-1055.

Bertrand, Marianne, Sendhil Mullainathan, and Eldar Shafir. "A Behavioral-Economics View of Poverty." American Economic Review 94, no. 2 (May 2004): 419-423.

Berube, Alan, Anne Kim, Benjamin Forman, and Megan Burns. "The Price of Paying Taxes: How Tax Preparation and Refund Loan Fees Erode the Benefits of the EITC." Washington, D.C.: Brookings Institution, Progressive Policy Institute Survey Series (May 2002). URL: http://www.brookings.edu/metro/publications/berubekimeitcexsum.html.

Bettinger, Eric. "How Financial Aid Affects Persistence," In College Choices: The Economics of Where to Go, When to Go, and How To Pay for It, edited by Caroline Hoxby, 207-238. Chicago: University of Chicago Press, 2004.

Bitler, Marianne, Janet Currie and John Karl Scholz. "WIC Participation and Eligibility", Journal of Human Resources, v38, 2003, 1139-1179.

Blumenthal, Marsha and Joel Slemrod. "The Compliance Cost of the U.S. Individual Income Tax System: A Second Look After Tax Reform." National Tax Journal 45, no. 2 (June 1992): 185-202. 
Brien, Michael J. and Christopher A. Swann. "Prenatal WIC Participation and Infant Health: Selection and Maternal Fixed Effects." University of Virginia Dept. of Economics, unpublished manuscript, 1999.

College Board. Trends in Student Aid 2005. New York: College Board Publications, 2005.

Currie, Janet. "The take up of social benefits." NBER Working Paper No. 10488. Cambridge, MA: National Bureau of Economic Research (2004).

Duffy, Elizabeth and Idana Goldberg. Crafting a Class: College Admissions and Financial Aid, 1955-1994. Ewing, NJ: Princeton University Press, 1998..

Dynarski, Susan M. "Hope for Whom? Financial Aid for the Middle Class and Its Impact on College Attendance.” National Tax Journal 53, no. 3 (Part 2 Sept. 2000): 629-661.

Dynarski, Susan M. "Does Aid Matter? Measuring the Effect of Student Aid on College Attendance and Completion." American Economic Review 93, no. 1 (March 2003): 279-288.

Dynarski, Susan M. "The New Merit Aid.” In College Choices: The Economics of Where to Go, When to Go, and How To Pay for It, edited by Caroline Hoxby. Chicago: University of Chicago Press, 2004a.

Dynarski, Susan M. “Tax policy and education policy: Collision or coordination?” In Tax Policy and the Economy, edited by James M. Poterba. Cambridge, MA: MIT Press, 2004b.

Dynarski, Susan M. "Building the Stock of College-Educated Labor." NBER Working Paper No. 11604 (September 2005).

Edlin, Aaron S. "Is College Financial Aid Equitable and Efficient?” Journal of Economic Perspectives 7, no. 2 (Spring 1993): 143-158.

Greenstein, Robert. "The Earned Income Tax Credit: Boosting Employment, Aiding the Working Poor." Washington, D.C.: Center for Budget and Policy Priorities (August 2005). URL: http://www.cbpp.org/7-19-05eic.htm

Hansen, W. Lee. "The Impact of Student Financial Aid on Access." In The Crisis in Higher Education, edited by Joseph Froomkin. New York: Academy of Political Science, 1983.

Henry, Gary, Steve Harkreader, Philo A. Hutcheson and Craig S. Gordon (1998). "Hope Longitudinal Study, First-Year Results." Unpublished manuscript, Georgia State University.

Kahneman, Daniel and Amos Tversky. Choices, Values and Frames. Cambridge, MA: Cambridge University Press, 2000. 
Kane, Thomas J. "Rising Public College Tuition and College Entry: How Well Do Public Subsidies Promote Access to College?” NBER Working Paper 5164, 1995.

Kane, Thomas J. "A Quasi-Experimental Estimate of the Impact of Financial Aid on CollegeGoing.” National Bureau of Economic Research Working Paper 9703, 2003.

Kaplow, Louis. "Optimal Taxation with Costly Enforcement and Evasion." Journal of Public Economics 43, no. 2 (November 1990): 221-236.

Kaplow, Louis. "How Tax Complexity and Enforcement Affect the Equity and Efficiency of the Income Tax." National Tax Journal 49, no. 1 (March 1996): 135-150.

Liebman, Jeffrey. "The Impact of the Earned Income Tax Credit on Incentives and Income Distribution," Tax Policy and the Economy No. 12 (1998).

Liebman, Jeffrey and Richard Zeckhauser. "Schmeduling." Harvard University, unpublished manuscript, 2004.

Madrian, Brigitte C. and Dennis F. Shea. "The Power of Suggestion: Inertia in 401(k) Participation and Savings Behavior." Quarterly Journal of Economics CXVI No. 4 (November 2001): 1149-1187.

Moffitt, Robert. "An Economic Model of Welfare Stigma." American Economic Review 73 No. 5 (December 1983): 1023-1035.

Mullainathan, Sendhil, and Richard H. Thaler. "Behavioral economics." NBER Working Paper No. 7948. Cambridge, MA: National Bureau of Economic Research (2000).

Nichols, Albert L., Richard J. Zeckhauser. "Targeting Transfers through Restrictions on Recipients.” American Economic Review 72, no. 2 (May 1982): 372-377.

O'Donoghue, Ted and Matthew Rabin. "Doing It Now or Later," The American Economic Review, 89 \#1, March 1999, 103-124.

President's Advisory Panel on Federal Tax Reform. Final Report of the President's Advisory Panel on Federal Tax Reform. Washington, D.C.: U.S. Government Printing Office, 2005. URL: http://www.taxreformpanel.gov/final-report/.

Samuelson, William and Richard Zeckhauser. "Status quo bias in decision making." Journal of Risk and Uncertainty 1, Issue 1, March 1988: 7-59.

Seftor, Neil and Turner, Sarah. "Back to School: Federal Student Aid Policy and Adult College Enrollment." Journal of Human Resources 37:2 (2002): 336-352. 
Stedman, J. B. Federal Pell Grant Program of the Higher Education Act: Background and Reauthorization. Congressional Research Service Report for Congress, Order Code RL31668 (2003).

Stoll, Adam, and Stedman, James B. Federal Student Aid Need Analysis: Background and Selected Simplification Issues. Congressional Research Service Report for Congress, Order Code 32083 (2004).

Thaler, Richard H. "Psychology and Savings Policies." American Economic Review 84, no. 2 (May 1994): 186-192.

U.S. Department of Education. Final Audit Report of the Student Financial Aid Application Verification Process. Control Number ED-OIG/A06-A0020. Washington, DC: U.S. Department of Education, Office of the Inspector General (2002a). URL: http://www.ed.gov/about/offices/list/oig/auditreports/a06a0020.pdf.

U.S. Department of Education. National Education Longitudinal Survey of 1988: Public-Use Data and Electronic Codebook, Base Year Through Fourth Follow-Up. Washington, DC: National Center for Education Statistics (2002b).

U.S. Department of Education. Year 2000 Performance Report and 2002 Program Annual Plan, Volume 2: Individual Programs: Student Financial Assistance. Washington, DC: U.S. Department of Education, Office of Student Financial Assistance (2002c). (URL: http://www.ed.gov/pubs/AnnualPlan2002/rV170171-SFA-0412.pdf )

U.S. Department of Education. 2003-2004 Federal Student Aid Handbook. Washington, DC: U.S. Department of Education, Office of Federal Student Aid (2003a). URL: http://ifap.ed.gov/IFAPWebApp/currentSFAHandbooksYearPag.jsp?p1=2003$2004 \& p 2=c$

U.S. Department of Education. 2003-2004 Free Application for Federal Student Aid. Washington, DC: U.S. Department of Education, Office of Federal Student Aid (2003b).

U.S. Department of Education. 2003-2004 National Postsecondary Student Aid Survey: Restricted-Use Data and Electronic Codebook. Washington, DC: National Center for Education Statistics (2005a).

U.S. Department of Education,. 2005-2006 Federal Student Aid Handbook. Washington, DC: U.S. Department of Education, Office of Federal Student Aid (2005b). URL: http://ifap.ed.gov/IFAPWebApp/currentSFAHandbooksYearPag.jsp?p1=20052006\&p2 $=\mathrm{c}$.

U.S. Department of Education. 2006-2007 FAFSA On the Web Screenshots. Washington, DC: U.S. Department of Education, Office of Federal Student Aid (2005c). (October 2005). URL: http://ifap.ed.gov/eannouncements/1025fotwscreenshot0607.html. 
U.S. Department of Education. Draft Student Aid Report 2006-2007 Washington, DC: U.S. Department of Education, Office of Federal Student Aid (2005d). URL: http://ifap.ed.gov/sarmaterials/attachments/0607DraftSAR.pdf

U.S. Department of Education. 2006-2007 Free Application for Federal Student Aid. Washington, DC: U.S. Department of Education, Office of Federal Student Aid (2006).

U.S. Office of Management and Budget. Budget of the United States Government, Fiscal Year 2005, Federal Credit Supplement. Washington, D.C., 2005. (URL: http://www.whitehouse.gov/omb/budget/fy2005/ )

Wilkinson, Rupert. Aiding Students, Buying Students. Nashville, TN: Vanderbilt University Press, 2005. 
Figure 1. The Student Aid Application Process

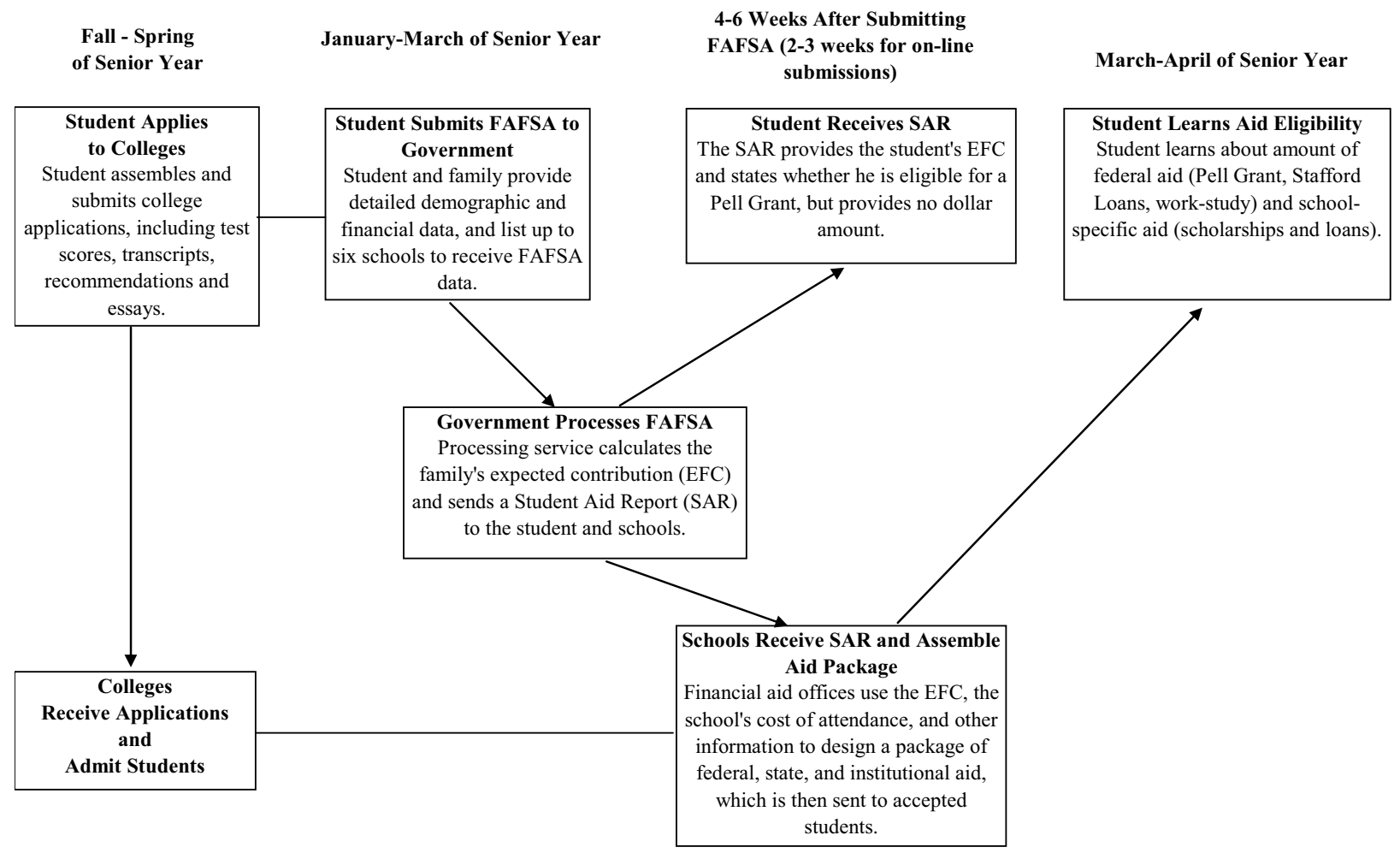


Table 1. Complexity of the FAFSA Versus IRS 1040

\begin{tabular}{|c|c|c|c|c|}
\hline Measure & $\begin{array}{l}1040 \\
2005\end{array}$ & $\begin{array}{r}1040 \mathrm{~A} \\
2005 \\
\end{array}$ & $\begin{array}{r}1040 \mathrm{EZ} \\
2005 \\
\end{array}$ & $\begin{array}{r}\text { FAFSA } \\
2006-2007 \\
\end{array}$ \\
\hline Number of pages (excluding instructions) & 2 & 2 & 1 & 5 \\
\hline Total number of questions & 118 & 83 & 37 & 127 \\
\hline \multicolumn{5}{|l|}{ Non-financial items } \\
\hline Identifying information & 6 & 6 & 6 & 22 \\
\hline Demographic/family information & 8 & 8 & 2 & 18 \\
\hline Enrollment status/school info. & 0 & 0 & 0 & 7 \\
\hline Signature and preparer info. & 12 & 12 & 12 & 8 \\
\hline Other & 1 & 1 & 1 & 10 \\
\hline \multicolumn{5}{|l|}{ Financial items } \\
\hline Earned income & 1 & 1 & 1 & 5 \\
\hline Other income & 19 & 12 & 2 & 33 \\
\hline Assets & 0 & 0 & 0 & 6 \\
\hline Deductions/credits/allowances & 39 & 22 & 2 & 12 \\
\hline Tax amounts from tables, calc. lines & 21 & 12 & 6 & 6 \\
\hline Withholdings, refund prefs. & 11 & 9 & 5 & 0 \\
\hline $\begin{array}{l}\text { Number of items required for } \\
\text { computation of tax/refund or aid amt.* }\end{array}$ & 71 & 43 & 8 & 72 \\
\hline Length of signing statement & 49 words & 64 words & 59 words & 232 words \\
\hline Official estimate of time to prepare ${ }^{* *}$ & 16 hours & 13 hours & 8 hours & 1 hour \\
\hline
\end{tabular}

Source: Authors' counts unless otherwise noted. Counts for the FAFSA are for dependent students with two parents, and includes questions on required student and parent worksheets. Total number of questions includes subquestions and non-numbered questions, and ensures that items such as name and address are counted in the same way on both IRS and FAFSA forms.

*For the FAFSA, this excludes items required only to determine dependency status or general eligibility for federal aid.

**Estimates from official Paperwork Reduction Act notices in the instructions accompanying each form. IRS-reported estimates of time and cost of preparation are based on non-business filers who selfprepare without tax preparation software (these estimates can be found in each form's instructions, on page 78,58 , and 23 , respectively). The FAFSA estimate can be found on page 7 of the FAFSA. 
Table 2. Simulations of Aid Simplification

\begin{tabular}{|c|c|c|c|}
\hline & $\begin{array}{r}\text { Sim (A) } \\
\text { Parents' AGI, } \\
\text { Student's AGI, } \\
\text { Assets, Family Info. }\end{array}$ & $\begin{array}{r}\text { Sim (B) } \\
\text { Parents' AGI, } \\
\text { Student's AGI, } \\
\text { Family Info. }\end{array}$ & $\begin{array}{r}\text { Sim }(\mathrm{C}) \\
\text { Parents' AGI } \\
\text { and Family Info }\end{array}$ \\
\hline \multicolumn{4}{|l|}{ Share of variance explained: } \\
\hline Pell & 0.90 & 0.86 & 0.77 \\
\hline Subsidized loan eligibility* & 0.79 & 0.76 & 0.76 \\
\hline $\mathrm{EFC}$ & 0.93 & 0.84 & 0.83 \\
\hline \multicolumn{4}{|l|}{$\begin{array}{l}\text { Share of students for whom } \\
\text { simulated Pell is: }\end{array}$} \\
\hline ...within $\$ 100$ of baseline & 0.77 & 0.76 & 0.71 \\
\hline ...within $\$ 500$ of baseline & 0.88 & 0.86 & 0.80 \\
\hline \multicolumn{4}{|l|}{$\begin{array}{l}\text { Share of students for whom } \\
\text { (Pell + Subs. loan eligibility) is: }\end{array}$} \\
\hline ...within $\$ 100$ of baseline & 0.58 & 0.56 & 0.54 \\
\hline ...within $\$ 500$ of baseline & 0.71 & 0.70 & 0.66 \\
\hline \multicolumn{4}{|l|}{ Variables included in simulation: } \\
\hline Assets & Y & & \\
\hline Student's AGI & Y & $\mathrm{Y}$ & \\
\hline Parental AGI & Y & Y & Y \\
\hline Parental marital status & $\mathrm{Y}$ & $\mathrm{Y}$ & $\mathrm{Y}$ \\
\hline Family size & $\mathrm{Y}$ & $\mathrm{Y}$ & $\mathrm{Y}$ \\
\hline Number of family members in coll. & $\mathrm{Y}$ & $\mathrm{Y}$ & Y \\
\hline Number of FAFSA items required for simulation* & 14 & 8 & 6 \\
\hline
\end{tabular}

SOURCE: Authors' calculations using FAFSA data from NPSAS: 2003-2004. Sample is limited to 15,603 dependent students who attended a single institution full time for the full school year. This excludes approximately $6 \%$ of the sample for whom we could not replicate the EFC and Pell amount within $\$ 1,000$ using the EFC formula and complete FAFSA data. All analyses use NPSAS-provided weights (STUDYWT). *Count refers to the number of questions on the 2003-2004 FAFSA required to elicit the items used in the simulated needs analysis. For example, eliciting the parents' state of residence requires 3 questions on the FAFSA. The count does not include questions used only to determine dependency status or questions unrelated to the calculation of need. The differences between the 2003-2004 and 2006-2007 FAFSA described in Table 1 are minor. 


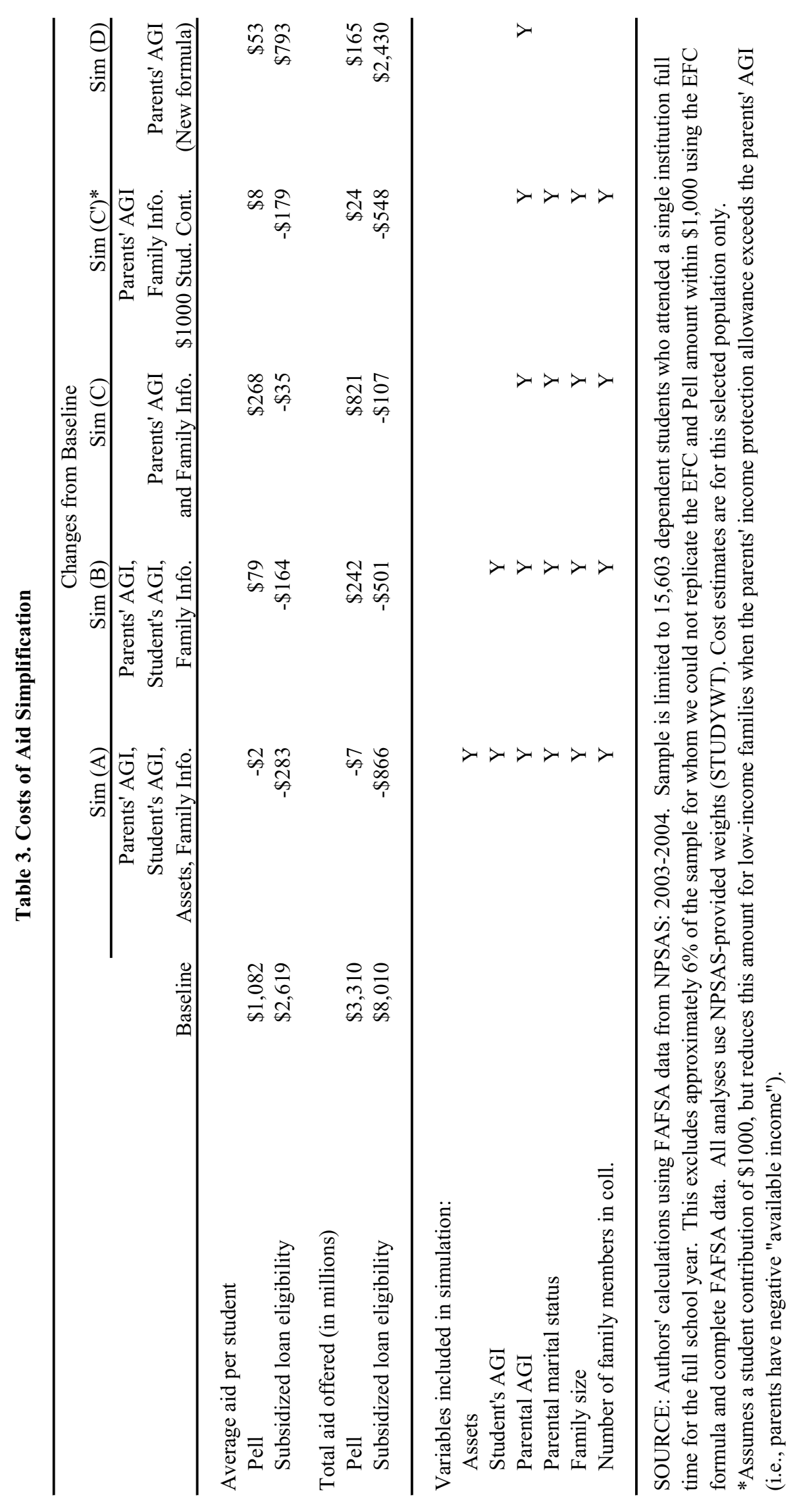


Figure 2.1. Distribution of Pell Grants by EFC,

Simulation A: Parents' and Student's AGI, Assets, and Basic Family Data

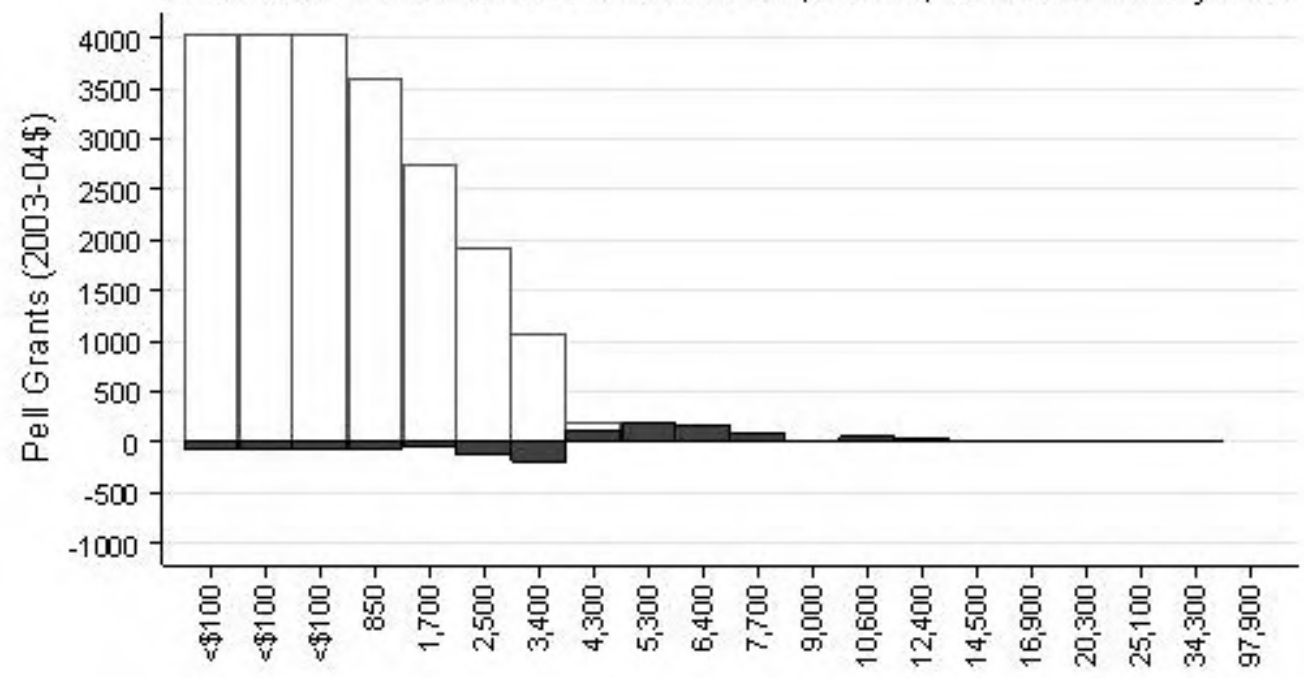

Baseline EFC Percentile (Label=Max EFC in Category)

\begin{tabular}{|l|l|}
\hline Current Average $\square$ Mean Change \\
\hline
\end{tabular}

Figure 2.2. Distribution of Subs. Loan Eligibility by EFC,

Simulation A: Parents' and Student's AGI, Assets, and Basic Family Data

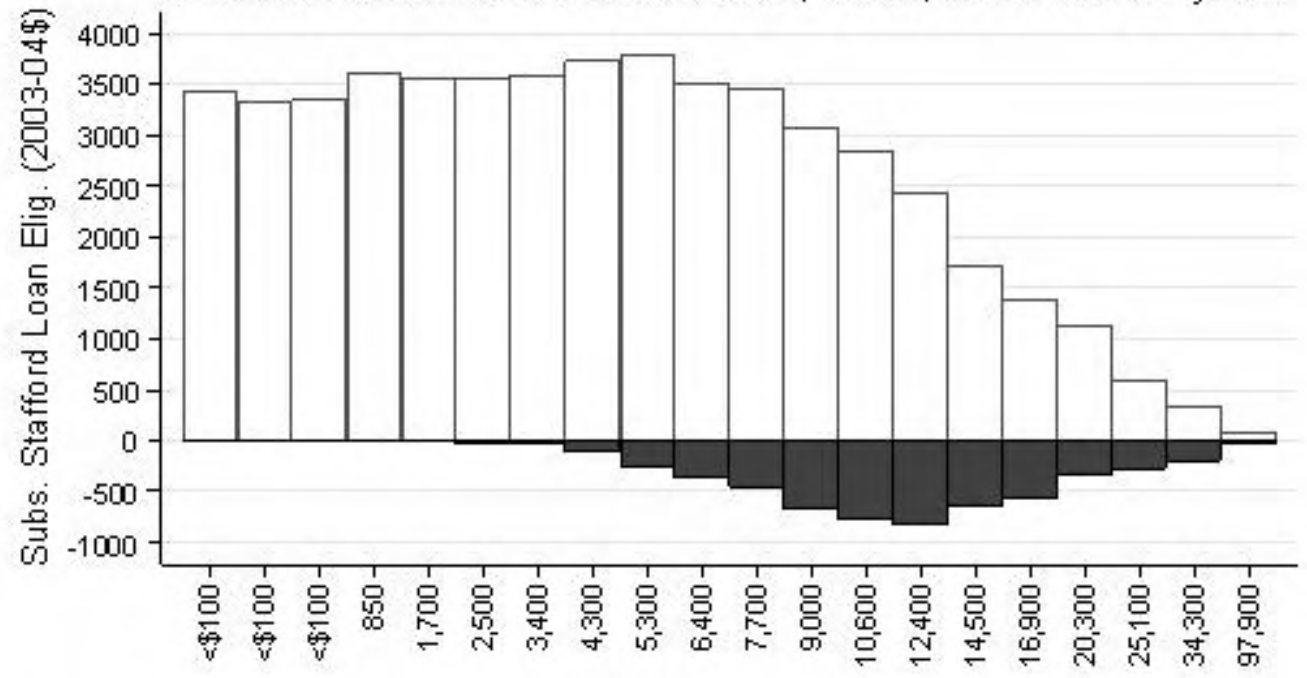

Baseline EFC Percentile (Label=Max EFC in Category)

\begin{tabular}{|l|l|}
\hline Curent Average $\square$ Mean Change \\
\hline
\end{tabular}


Figure 3.1. Distribution of Pell Grants by EFC,

Simulation B: Parents' and Student's AGI and Basic Family Data

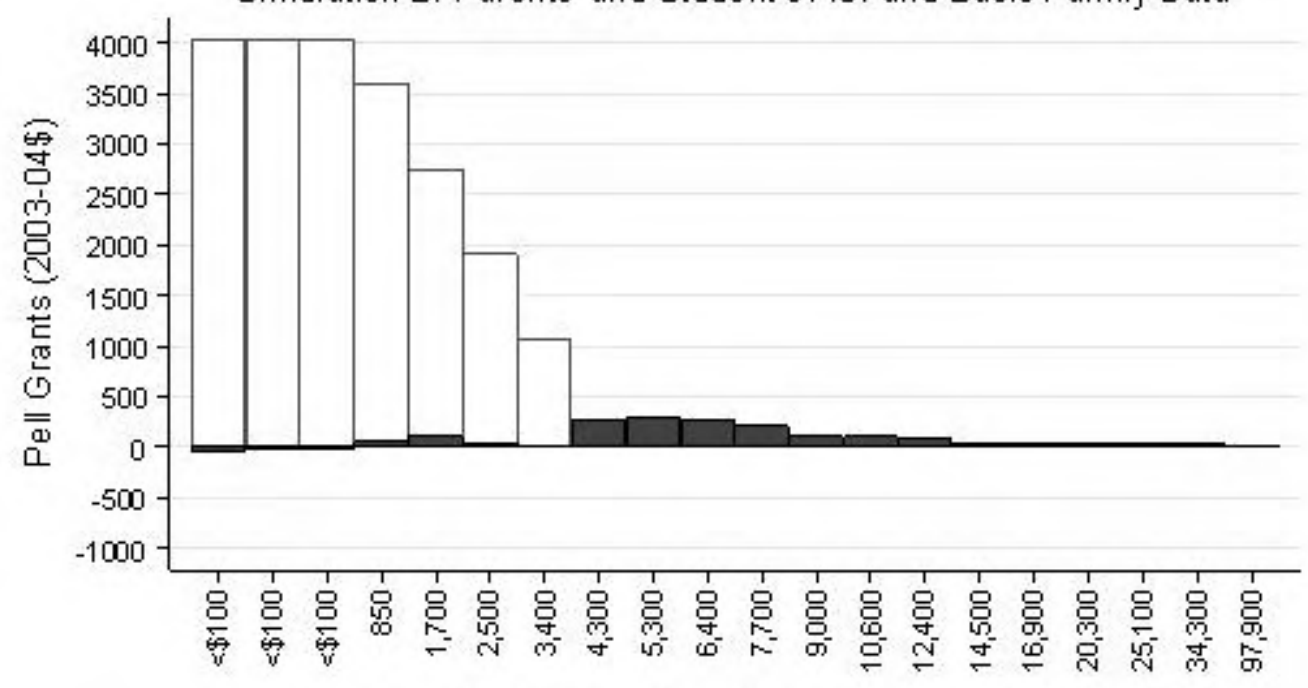

Baseline EFC Percentile (Label=Max EFC in Category)

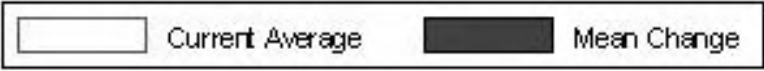

Figure 3.2. Distribution of Subs. Loan Eligibility by EFC, Simulation B: Parents' and Student's AGI and Basic Family Data

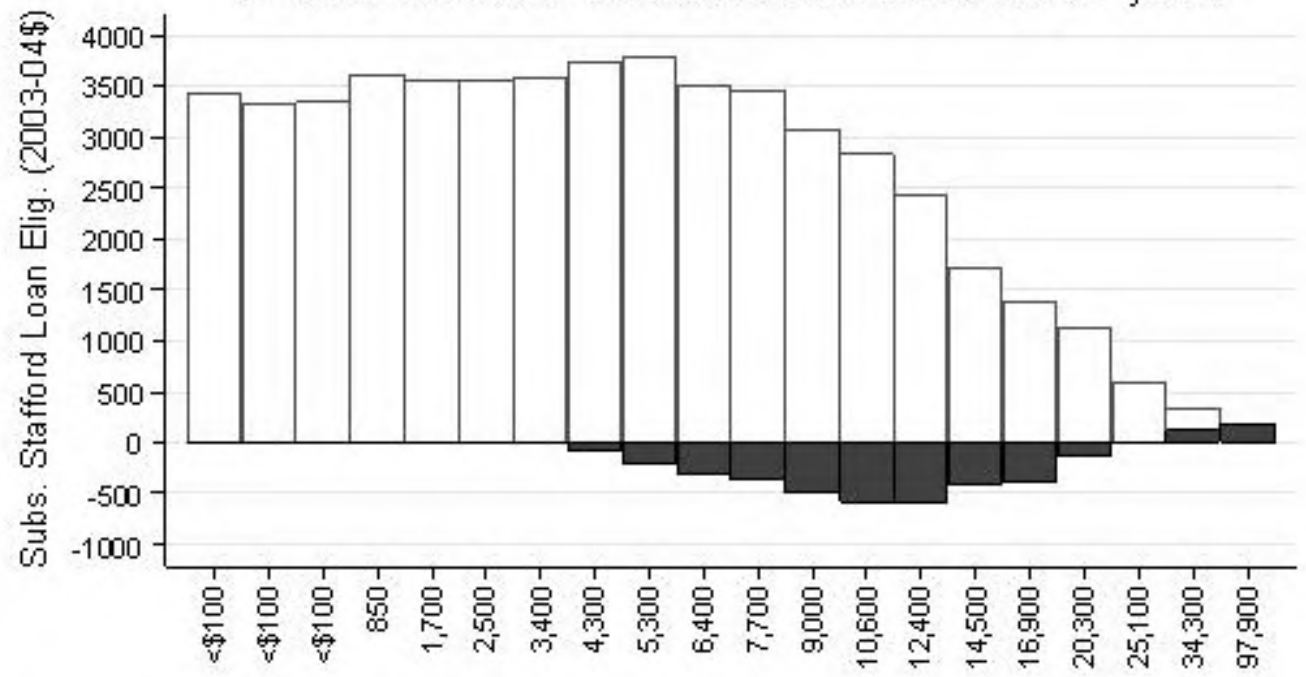

Baseline EFC Percentile (Label=Max EFC in Category)

\begin{tabular}{|l|l|}
\hline Currert Average $\square$ Mean Change \\
\hline
\end{tabular}


Figure 4.1. Distribution of Pell Grants by EFC, Using All Data Except Assets

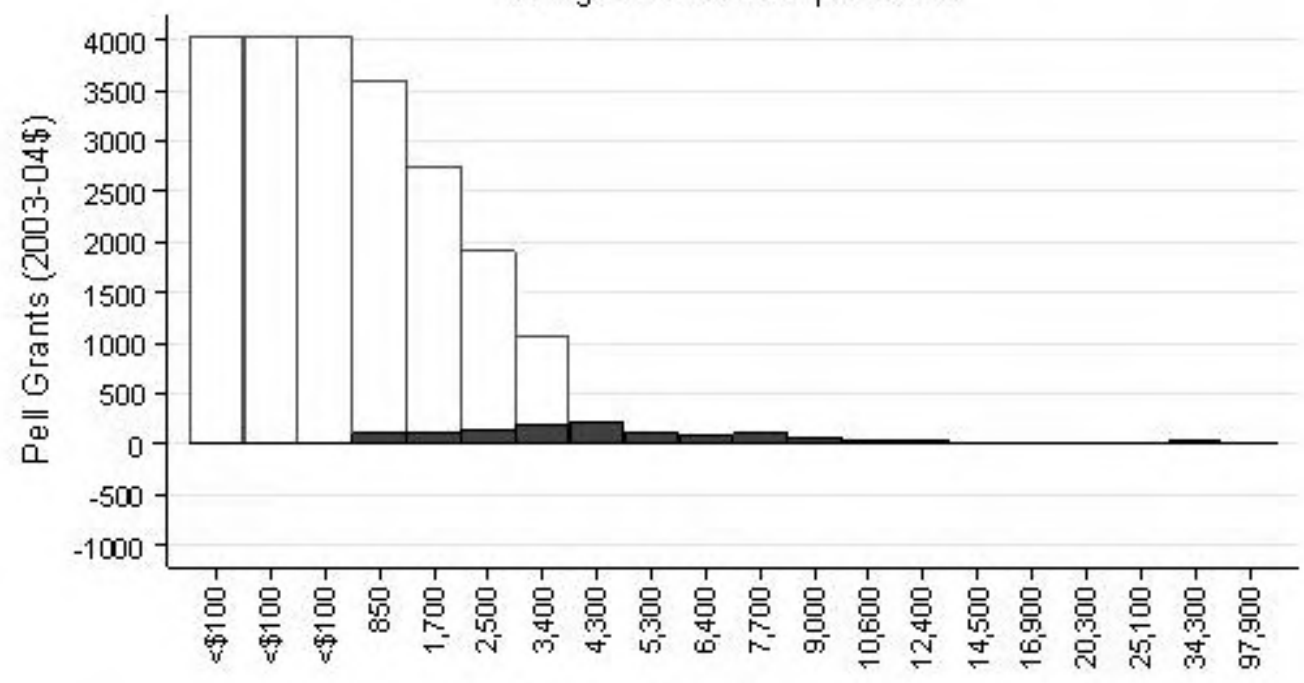

Baseline EFC Percentile (Label=Max EFC in Category)

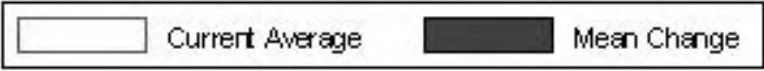

Figure 4.2. Distribution of Subs. Loan Eligibility by EFC, Using All Data Except Assets

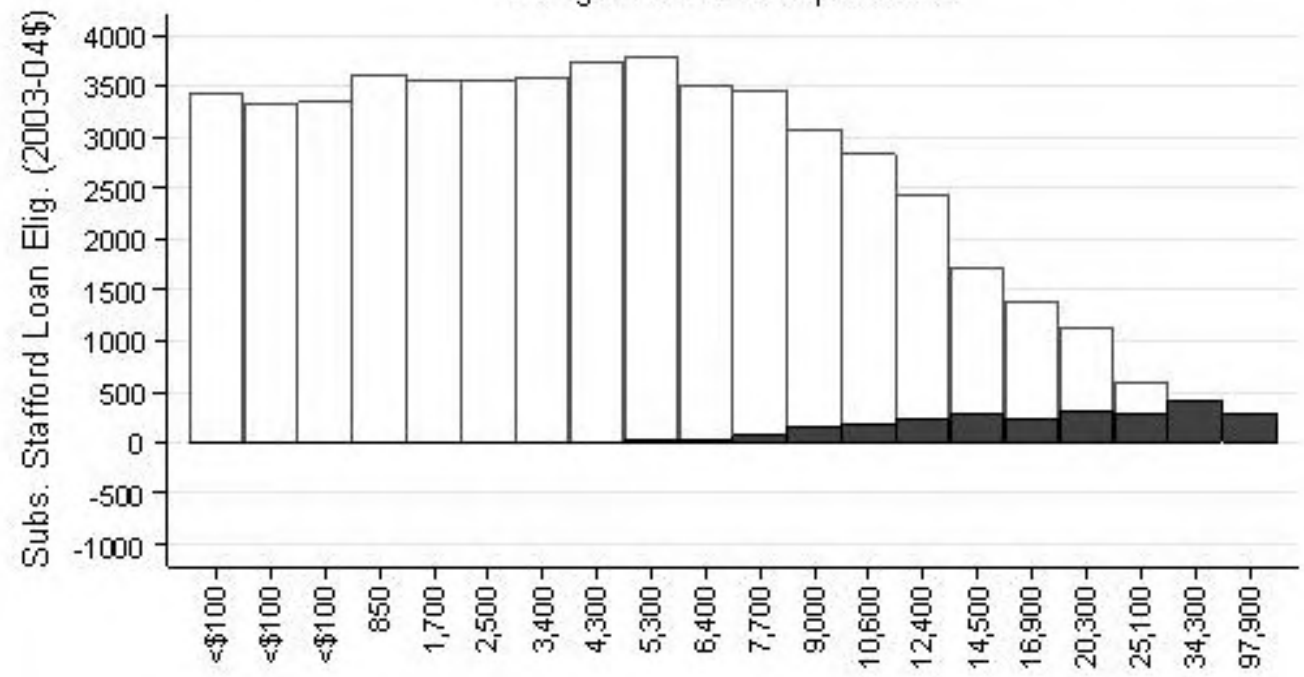

Baseline EFC Percentile (Label=Max EFC in Category)

\begin{tabular}{|l|l|}
\hline Currert Avarage $\square$ Mean Change \\
\hline
\end{tabular}


Figure 5.1. Distribution of Pell Grants by EFC, Simulation C: Parents' AGI and Basic Family Data

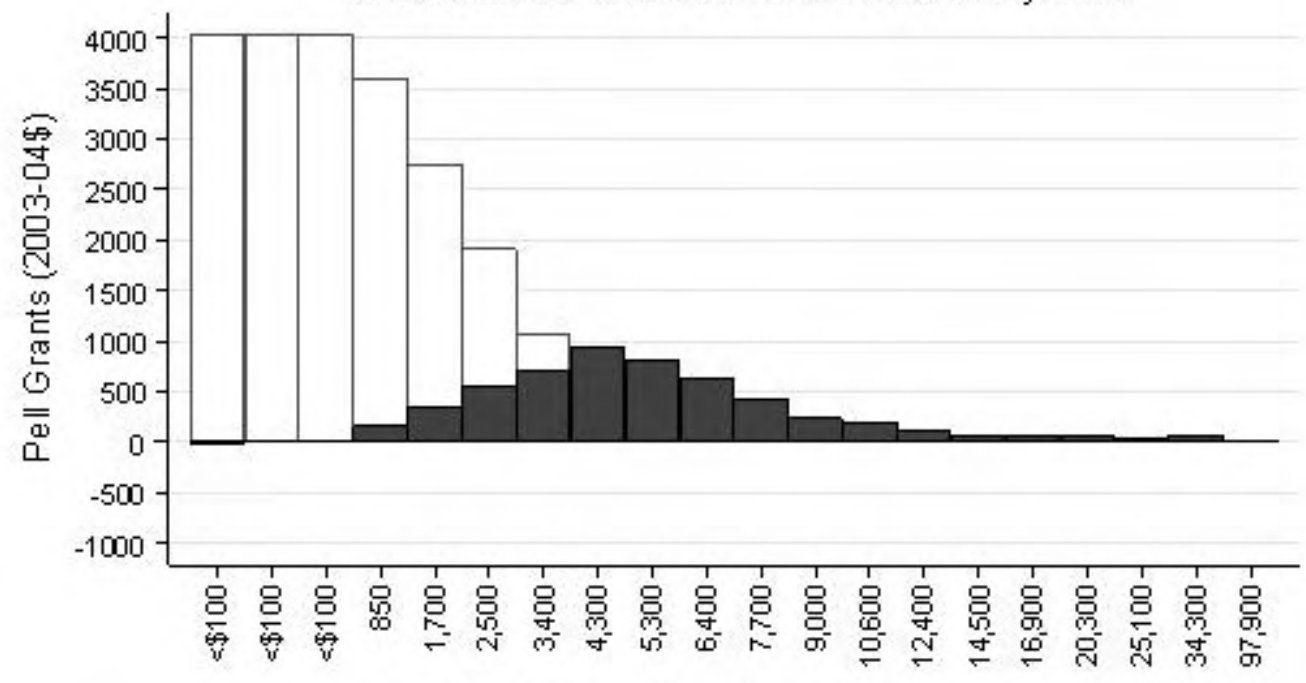

Baseline EFC Percentile (Label=Max EFC in Category)

\begin{tabular}{|l}
\hline Currert Awarage $\square$ Mean Change \\
\hline
\end{tabular}

Figure 5.2. Distribution of Subs. Loan Eligibility by EFC, Simulation C: Parents' AGI and Basic Family Data

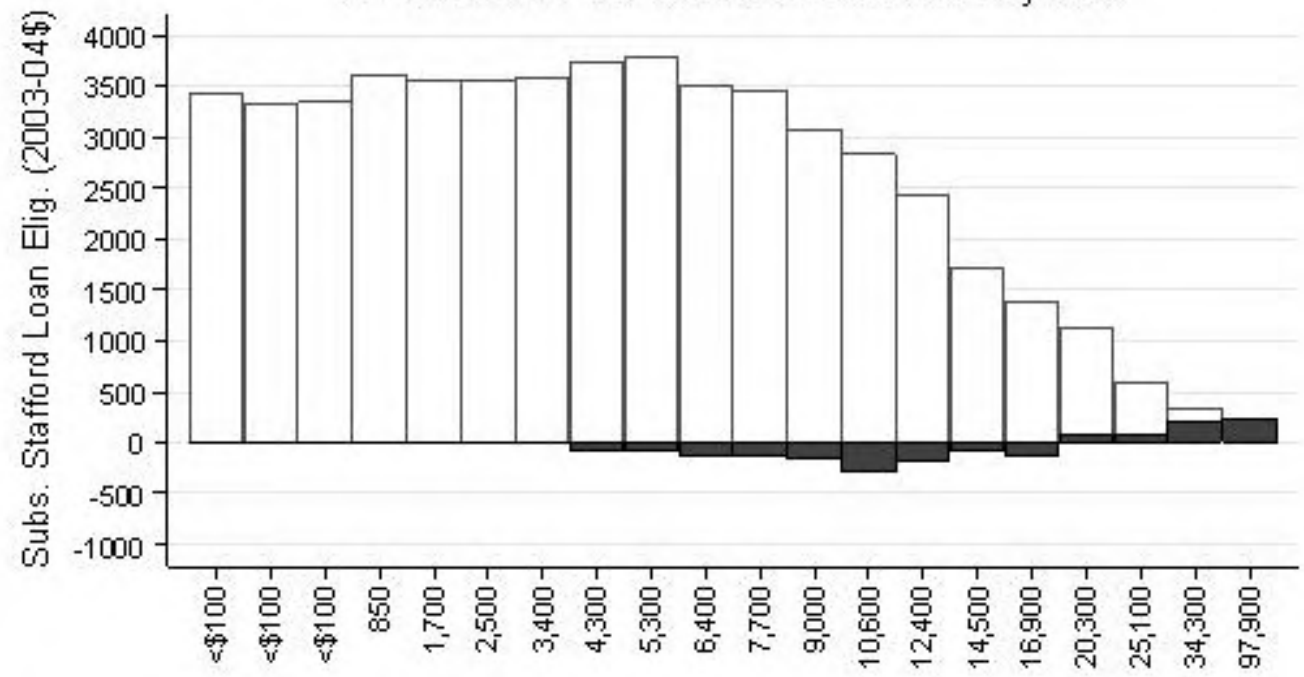

Baseline EFC Percentile (Label=Max EFC in Category)

\begin{tabular}{|l|l|}
\hline Currert Average $\square$ Mean Change \\
\hline
\end{tabular}


Figure 6.1. Distribution of Pell Grants by Parents' AGI, Simulation C': Parents' AGI and Basic Family Data, $\$ 1000$ Stud. Cont.

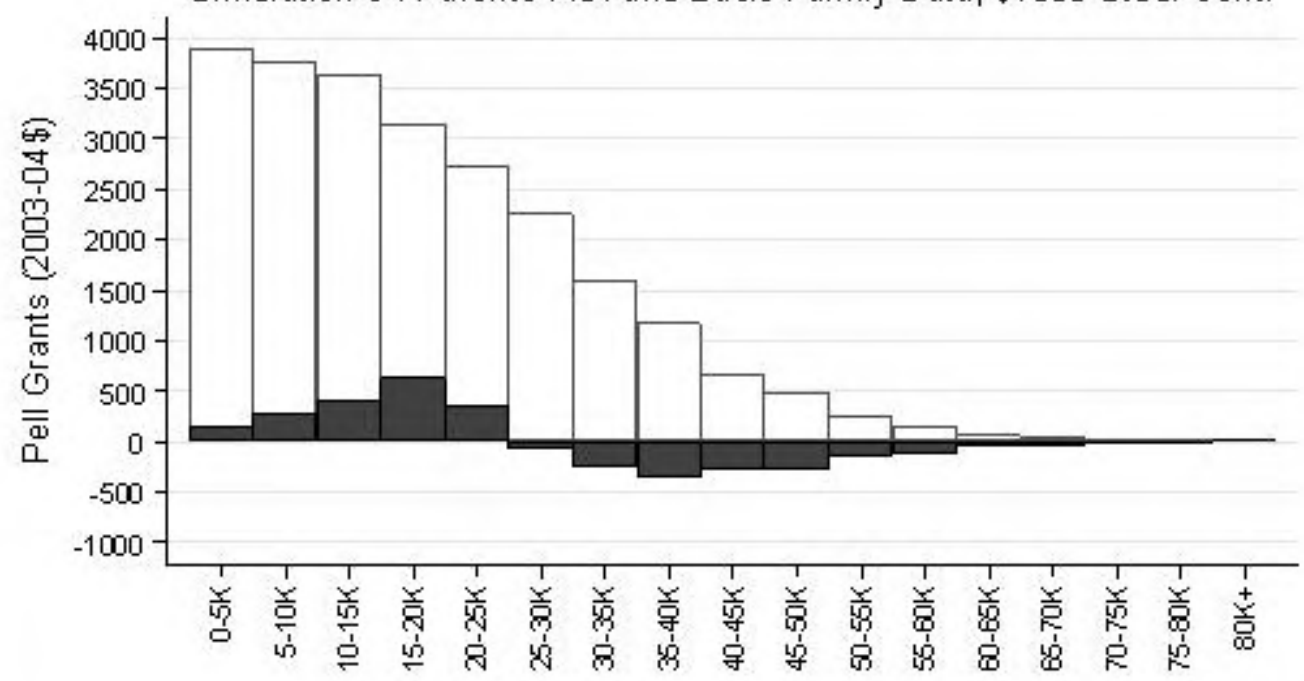

Parents' AGI

Figure 6.2. Distribution of Pell Grants by EFC,

Simulation C': Parents' AGI and Basic Family Data, $\$ 1000$ Stud. Cont.

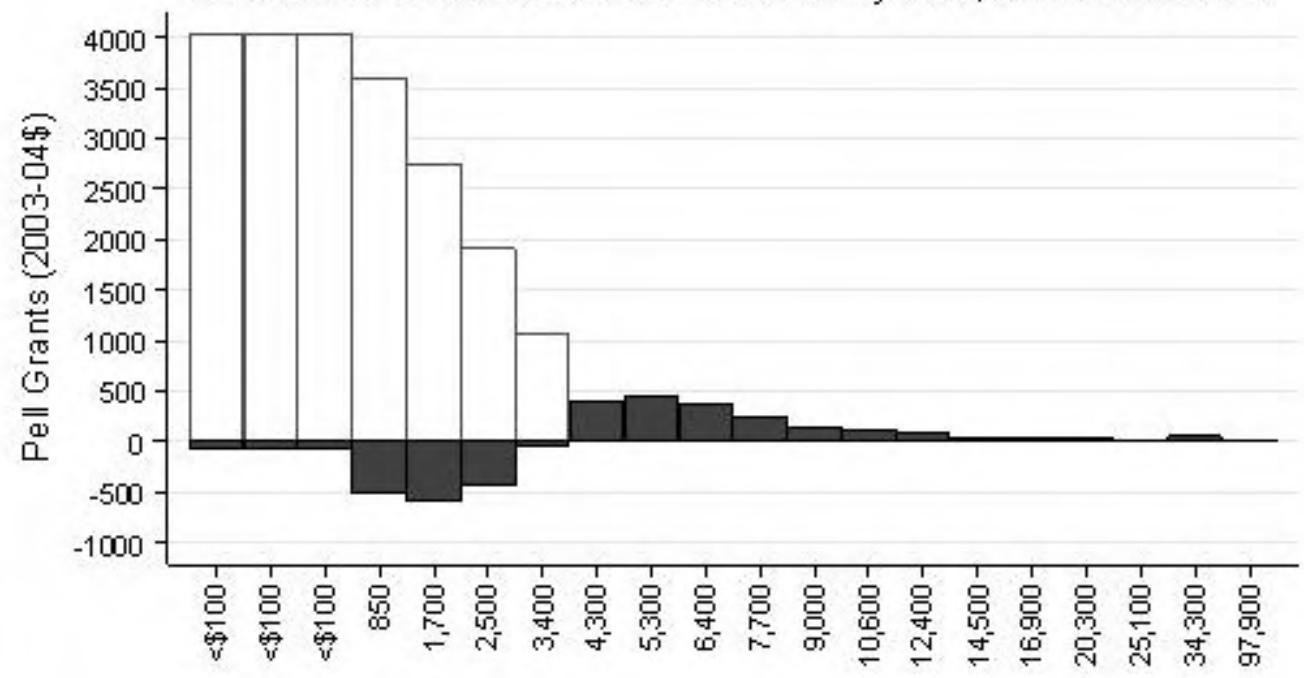

Baseline EFC Percentile (Label=Max EFC in Category)

\begin{tabular}{|l|l|}
\hline Currert Avarage $\square$ Mean Change \\
\hline
\end{tabular}


Exhibit 1. Federal Student Aid, on a Postcard

\begin{tabular}{|ccc|}
\hline \multicolumn{3}{|c|}{ How much federal aid can I get to help pay for college? } \\
$\begin{array}{c}\text { If your parents' } \\
\text { then your }\end{array}$ & $\begin{array}{c}\text { and your total } \\
\text { adjusted gross income is... }\end{array}$ & $\begin{array}{c}\text { Pell Grant is... } \\
\text { Pell Grant + subsidized loan is }\end{array}$ \\
$\$ 0-\$ 14,999$ & $\$ 4,000$ & $\$ 9,000$ \\
$\$ 15,000-\$ 19,999$ & $\$ 3,650$ & $\$ 8,650$ \\
$\$ 20,000-\$ 24,999$ & $\$ 3,150$ & $\$ 8,150$ \\
$\$ 25,000-\$ 29,999$ & $\$ 2,450$ & $\$ 7,450$ \\
$\$ 30,000-\$ 34,999$ & $\$ 1,750$ & $\$ 6,750$ \\
$\$ 35,000-\$ 39,999$ & $\$ 1,150$ & $\$ 6,150$ \\
$\$ 40,000-\$ 44,999$ & $\$ 550$ & $\$ 5,550$ \\
$\$ 45,000-\$ 49,999$ & $\$ 250$ & $\$ 5,250$ \\
$\$ 50,000-\$ 74,999$ & $\$ 0$ & $\$ 5,000$ \\
$\$ 75,000$ or higher & $\$ 0$ & $\$ 0$ \\
Unsubsidized loans are available for all students up to the cost of attendance \\
(including tuition, fees, and living expenses) at your institution. \\
Average tuition and fees are $\$ 5,500$ at public 4-year institutions \\
$95 \%$ of public 4-year institutions have tuition and fees below $\$ 9,000$
\end{tabular}


Figure 7.1. Distribution of Pell Grants by Parents' AGI, Simulation D: Parents' AGl (New Aid Formula)

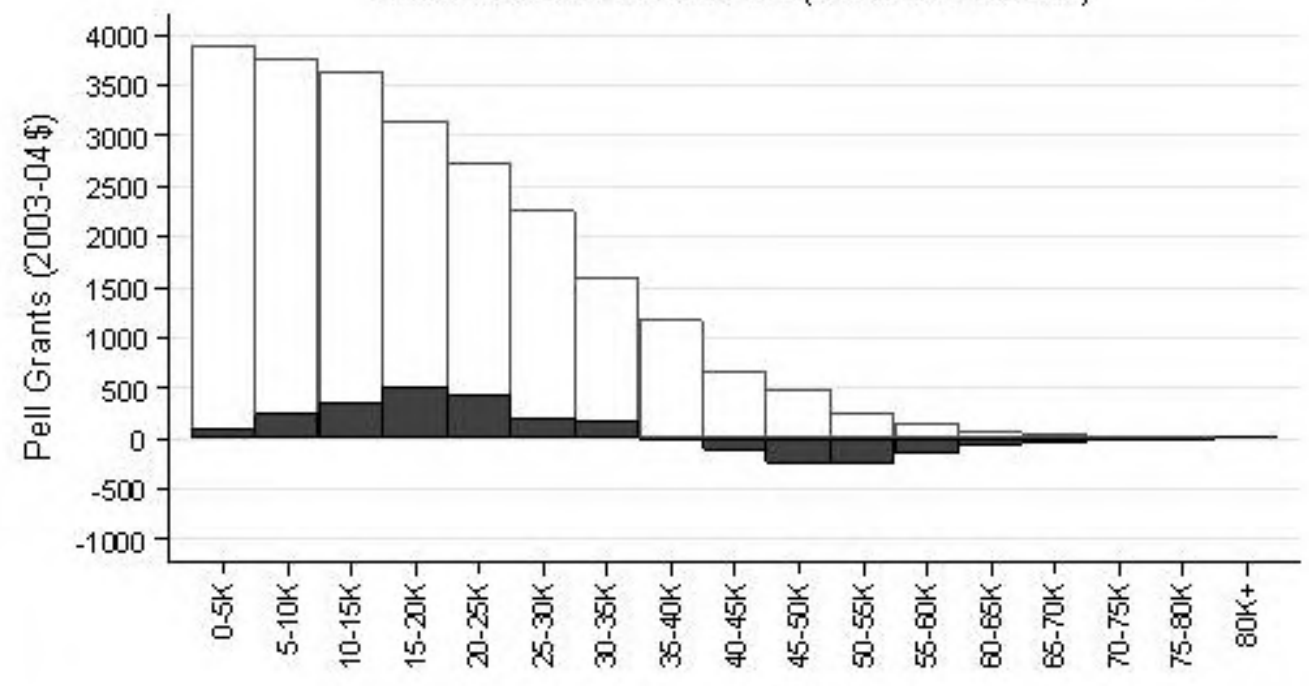

Parents' AGI

\section{Currert Average $\square$ Mean Change}

Figure 7.2. Distribution of Pell Grants by EFC, Simulation D: Parents' AGI (New Aid Formula)

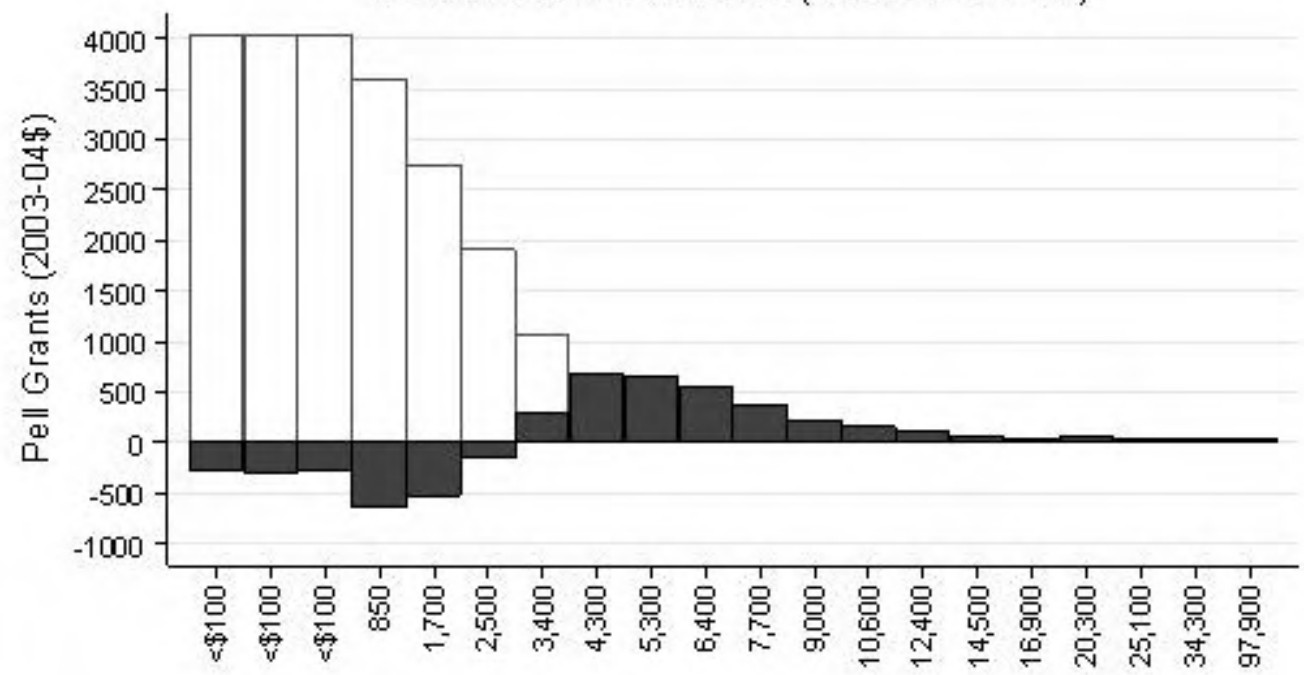

Baseline EFC Percentile (Label=Max EFC in Category)

\begin{tabular}{|l|l|}
\hline Currert Avarage $\square$ Mean Change \\
\hline
\end{tabular}




\section{$\underline{\text { Appendix }}$}

\section{Data}

Student aid statistics and simulations are based on restricted-use, individual-level data from the nationally representative 2003-04 National Postsecondary Student Aid Survey (NPSAS:04). NPSAS:04 includes data from the Free Application for Federal Student Aid (FAFSA) for 53,025 undergraduate federal aid applicants. We limited our sample to full-time, dependent undergraduates who attended the same institution for the full year. 47 percent of aid applicants are dependents, and of these, 61 percent attended a single institution full time for the full year. This yields an initial sample of 17,064. From this sample we drop 460 individuals ( 2.5 percent) who were missing the EFC, family size, or number of family members in college. We drop 1,001 individuals (6 percent) whose EFC and Pell awards could not be replicated within $\$ 1,000$ using the published aid formulas (described below).

\section{Aid Formulas}

To replicate the student's EFC, Pell, and subsidized Stafford eligibility, as well as to test the consequences of formula simplification, we coded EFC, Pell, and Stafford loan formulas and rules for dependent students as outlined in the 960-page 2003-2004 Federal Student Aid Handbook.

The EFC formula sums parents' adjusted gross income (or W-2 earnings for nontax-filers) and other income, subtracts a number of allowances (of which the largest is the amount of taxes paid), and adds in 12 percent of assets over an asset protection threshold that depends on marital status and elder parent's age. Marginal assessment rates from 22 to 47 percent are applied to this total (called parents" "adjusted available income"). The result is divided by the number of children in college to obtain the parents' expected contribution. The student's expected contribution is computed by adding student's adjusted gross income and other income, subtracting a few allowances, and applying a 50 percent assessment rate. 35 percent of any student assets are added to this figure to yield the student's expected contribution (students have no asset protection allowance).

The Pell award is estimated by subtracting the EFC from the maximum Pell Grant $(\$ 4,050)$. Following federal rules, grants between zero and $\$ 199$ are rounded down to zero and grants between $\$ 200$ and $\$ 399$ are rounded up to the minimum grant of $\$ 400$. Pell Grants over $\$ 2,700$ are adjusted downwards for students at very low-tuition institutions (tuition and fees less than $\$ 675$, in 2003-2004) using what is called the "tuition sensitivity adjustment." Pell Grants are also reduced if the calculated amount exceeds the cost of attendance at the student's institution (which is provided in NPSAS, as reported by the schools). In our sample, the tuition sensitivity adjustment applied to only 35 people and the cost of attendance adjustment applied to none.

Subsidized Stafford loan eligibility is estimated by subtracting the estimated EFC, estimated Pell grant, and any other grants from the cost of attendance. The result is capped at the maximum loan amount for the student's class level, which in 2003-2004 was $\$ 2,625$ for first-year students, $\$ 3,500$ for second-years, and $\$ 5,500$ for third and fourth-year dependent undergraduates. 


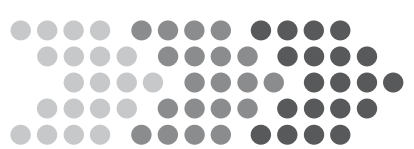

Use this form to apply free for federal and state student grants, work-study and loans.

Or apply free online at www.fafsa.ed.gov.

\section{Applying by the Deadlines}

For federal aid, submit your application as early as possible, but no earlier than January 1, 2006. We must receive your application no later than July 2, 2007. Your college must have your correct, complete information by your last day of enrollment in the 2006-2007 school year.

For state or college aid, the deadline may be as early as January 2006. See the table to the right for state deadlines. You may also need to complete additional forms. Check with your high school guidance counselor or a financial aid administrator at your college about state and college sources of student aid and deadlines.

If you are filing close to one of these deadlines, we recommend you file online at www.fafsa.ed.gov. This is the fastest and easiest way to apply for aid.

\section{Using Your Tax Return}

If you are supposed to file a 2005 federal income tax return, we recommend that you complete it before filling out this form. If you have not yet filed your return, you can still submit your FAFSA, but you must provide income and tax information. Once you file your tax return, correct any income or tax information that is different from what you initially submitted on your FAFSA.

\section{Filling Out the FAFSA}

Your answers on this form will be read electronically. Therefore:
- use black ink and fill in ovals completely:

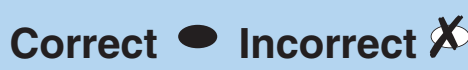
- print clearly in CAPITAL letters and skip a box between words:
- report dollar amounts (such as $\$ 12,356.41)$ like this:

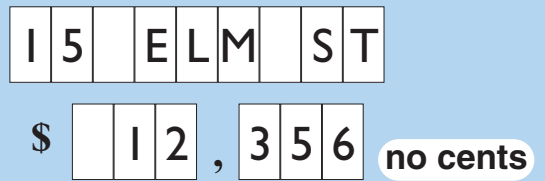

Blue is for student information and purple is for parent information.

If you or your family has unusual circumstances (such as loss of employment), complete this form to the extent you can, then submit it as instructed and consult with the financial aid office at the college you plan to attend.

For more information or help in filling out the FAFSA, call 1-800-4-FED-AID (1-800433-3243). TTY users may call 1-800-730-8913. Or visit our Web site at www.studentaid.ed.gov.

\section{Mailing Your FAFSA}

After you complete this application, make a copy of pages 3 through 6 for your records. Then mail the original of only pages 3 through 6 in the attached envelope or send it to: Federal Student Aid Programs, P.O. Box 4691, Mt. Vernon, IL 62864-0059. Do not send the worksheets on page 8 ; keep them for your records.

If you do not receive the results of your application - a Student Aid Report (SAR) within three weeks, please check online at www.fafsa.ed.gov or call 1-800-433-3243. If you provided your e-mail address in question 13, you will receive information about your application within a few days after we process it.

\section{Let's Get Started!}

\section{STATE AID DEADLINES}

File Online and File On Time www.fafsa.ed.gov

AK April 15, 2006 (date received)

AR For Academic Challenge - June 1, 2006 (date received)

For Workforce Grant - Contact your financial aid administrator.

AZ June 30, 2007 (date received)

*^CA For initial awards - March 2, 2006

For additional community college awards September 2, 2006 (date postmarked)

* DC June 30, 2006 (date received by state)

DE April 15, 2006 (date received)

FL May 15, 2006 (date processed)

$\wedge$ IA July 1, 2006 (date received)

\#IL First-time applicants - September 30, 2006 Continuing applicants - August 15, 2006 (date received)

IN March 10, 2006 (date received)

\#*KS April 1, 2006 (date received)

\#KY March 15, 2006 (date received)

\#^LA May 1, 2006

Final deadline - July 1, 2006 (date received)

$\#^{\wedge}$ MA May 1, 2006 (date received)

MD March 1, 2006 (date received)

ME May 1, 2006 (date received)

MI March 1, 2006 (date received)

MN 30 days after term starts (date received)

MO April 1, 2006 (date received)

\#MT March 1, 2006 (date received)

NC March 15, 2006 (date received)

ND March 15, 2006 (date received)

$\mathrm{NH}$ May 1, 2006 (date received)

${ }^{\wedge}$ NJ June 1, 2006, if you received a Tuition Aid Grant in 2005-2006

All other applicants

- October 1, 2006, fall \& spring terms

- March 1, 2007, spring term only

(date received)

${ }^{* \wedge} \mathrm{NY}$ May 1, 2007 (date received)

$\mathrm{OH}$ October 1, 2006 (date received)

\#OK April 15, 2006

Final deadline - June 30, 2006

(date received)

\#OR March 1, 2006 (date received)

Final deadline - Contact your financial aid administrator.

* PA All 2005-2006 State Grant recipients \& all non-2005-2006 State Grant recipients in degree programs - May 1, 2006 All other applicants - August 1, 2006 (date received)

\#RI March 1, 2006 (date received)

SC June 30, 2006 (date received)

TN For State Grant - May 1, 2006

For State Lottery - September 1, 2006 (date received)

*^ WV March 1, 2006 (date received)

Check with your financial aid administrator for these states and territories:

$\mathrm{AL},{ }^{*} \mathrm{AS}, \mathrm{CO},{ }^{*} \mathrm{CT},{ }^{*} \mathrm{FM}, \mathrm{GA},{ }^{*} \mathrm{GU},{ }^{*} \mathrm{HI}, \mathrm{ID}$,

${ }^{*} \mathrm{MH},{ }^{*} \mathrm{MP}, \mathrm{MS},{ }^{*} \mathrm{NE},{ }^{*} \mathrm{NM},{ }^{*} \mathrm{NV}, \mathrm{PR},{ }^{*} \mathrm{PW}$,

${ }^{*} \mathrm{SD}$, *TX, UT, *VA, "VI, *VT, WA, WI and ${ }^{*} \mathrm{WY}$.

\# For priority consideration, submit application by date specified.

^ Applicants encouraged to obtain proof of mailing.

Additional form may be required.

ISD5472 
If you are an eligible noncitizen, write in your eight- or nine-digit Alien Registration Number. Generally, you are an eligible noncitizen if you are (1) a U.S. permanent resident with a Permanent Resident Card (I-551); (2) a conditional permanent resident (I-551C); or (3) the holder of an Arrival-Departure Record (I-94) from the Department of Homeland Security showing any one of the following designations: "Refugee," "Asylum Granted," "Parolee" (I-94 confirms paroled for a minimum of one year and status has not expired) or "Cuban-Haitian Entrant." If you are in the U.S. on an F1 or F2 student visa, a J1 or J2 exchange visitor visa, or a G series visa (pertaining to international organizations), you must fill in oval c. If you are neither a citizen nor an eligible noncitizen, you are not eligible for federal student aid. However, you may be eligible for state or college aid.

\section{Notes for question 23 (page 3) - Enter the correct number in the box in question 23.}

Enter 1 for $1^{\text {st }}$ bachelor's degree.

Enter 2 for $2^{\text {nd }}$ bachelor's degree.

Enter 3 for associate degree (occupational or technical program).

Enter 4 for associate degree (general education or transfer program).

Enter $\mathbf{5}$ for certificate or diploma for completing an occupational, technical, or educational program of less than two years.
Enter 6 for certificate or diploma for completing an occupational, technical, or educational program of at least two years.

Enter 7 for teaching credential program (nondegree program).

Enter $\mathbf{8}$ for graduate or professional degree.

Enter 9 for other/undecided.

\section{Notes for question 24 (page 3) - Enter the correct number in the box in question 24.}

Enter 0 for never attended college \& 1st year undergraduate.

Enter 1 for attended college before \& 1st year undergraduate.

Enter 2 for 2 nd year undergraduate/sophomore.

Enter 3 for 3rd year undergraduate/junior.
Enter 4 for 4 th year undergraduate/senior.

Enter 5 for 5 th year/other undergraduate.

Enter $\mathbf{6}$ for 1 st year graduate/professional.

Enter 7 for continuing graduate/professional or beyond.

\section{Notes for questions $\mathbf{2 9}$ - $\mathbf{3 0}$ (page 3)}

Some states and colleges offer aid based on the level of schooling your parents completed.

\section{Notes for questions 33 c. and d. (page 4) and 71 c. and d. (page 5)}

If you filed or will file a foreign tax return, or a tax return with Puerto Rico, Guam, American Samoa, the U.S. Virgin Islands, the Marshall Islands, the Federated States of Micronesia, or Palau, use the information from that return to fill out this form. If you filed a foreign return, convert all figures to U.S. dollars, using the exchange rate that is in effect today. To view the daily exchange rate, go to www.federalreserve.gov/releases/h10/update.

\section{Notes for questions 34 (page 4) and 72 (page 5)}

In general, a person is eligible to file a 1040A or 1040EZ if he or she makes less than $\$ 100,000$, does not itemize deductions, does not receive income from his or her own business or farm, and does not receive alimony. A person is not eligible if he or she itemizes deductions, receives self-employment income or alimony, or is required to file Schedule D for capital gains. If you filed a 1040 only to claim Hope or Lifetime Learning credits, and you would have otherwise been eligible for a 1040A or 1040EZ, you should answer "Yes" to this question.

\section{Notes for questions 37 (page 4) and 75 (page 5) - Notes for those who filed a 1040EZ}

On the 1040EZ, if a person answered "Yes" on line 5, use EZ worksheet line F to determine the number of exemptions ( $\$ 3,200$ equals one exemption). If a person answered "No" on line 5, enter 01 if he or she is single, or 02 if he or she is married.

\section{Notes for questions 43 - 45 (page 4) and 81 - 83 (page 5)}

By applying online at www.fafsa.ed.gov, you may be eligible to skip some questions. If you do not apply online, you will not be penalized for completing questions 43-45 and 81-83 on the paper FAFSA.

Net worth means current value minus debt. If net worth is one million dollars or more, enter $\$ 999,999$. If net worth is negative, enter 0 .

Investments include real estate (do not include the home you live in), trust funds, money market funds, mutual funds, certificates of deposit, stocks, stock options, bonds, other securities, Coverdell savings accounts, college savings plans, installment and land sale contracts (including mortgages held), commodities, etc. For more information about reporting education savings plans, call 1-800-4333243. Investment value includes the market value of these investments as of today. Investment debt means only those debts that are related to the investments.

Investments do not include the home you live in, the value of life insurance, retirement plans (pension funds, annuities, noneducation IRAs, Keogh plans, etc.), and prepaid tuition plans, or cash, savings, and checking accounts already reported in 43 and 81.

Business and/or investment farm value includes the market value of land, buildings, machinery, equipment, inventory, etc. Business and/or investment farm debt means only those debts for which the business or investment farm was used as collateral.

\section{Notes for question 54 (page 4)}

Answer "No" (you are not a veteran) if you (1) have never engaged in active duty in the U.S. Armed Forces, (2) are currently an ROTC student or a cadet or midshipman at a service academy, or (3) are a National Guard or Reserves enlistee activated only for training. Also answer "No" if you are currently serving in the U.S. Armed Forces and will continue to serve through June $30,2007$.

Answer "Yes" (you are a veteran) if you (1) have engaged in active duty in the U.S. Armed Forces (Army, Navy, Air Force, Marines or Coast Guard) or are a National Guard or Reserve enlistee who was called to active duty for purposes other than training, or were a cadet or midshipman at one of the service academies, and (2) were released under a condition other than dishonorable. Also answer "Yes" if you are not a veteran now but will be one by June 30, 2007. 


\section{Step One: For questions 1-30, leave blank any questions that do not apply to you (the student).}

1-3. Your full name (as it appears on your Social Security card)

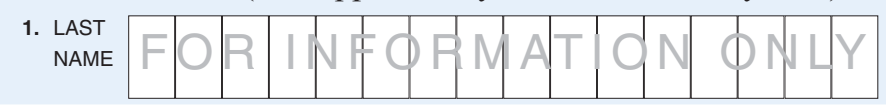

2. FIRST
NAME
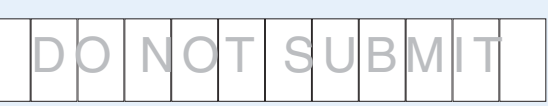

3. MIDDLE INITIAL

4-7. Your permanent mailing address

4. NUMBER AND STREET (INCLUDE APT. NUMBER)

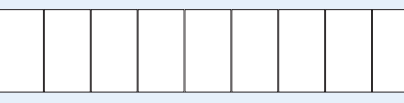

5. CITY (AND COUNTRY IF NOT U.S.)
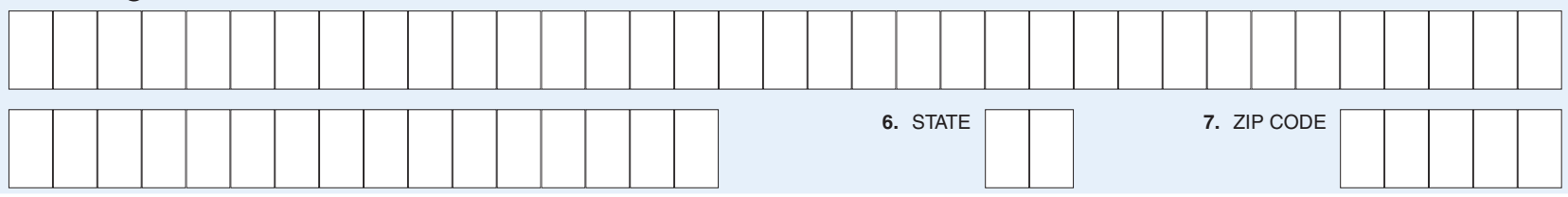

8. Your Social Security Number

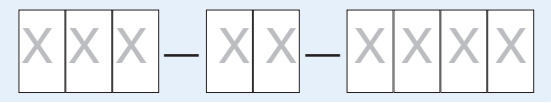

9. Your date of birth

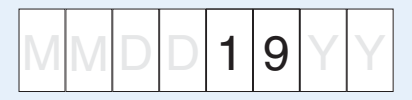

10. Your permanent telephone number

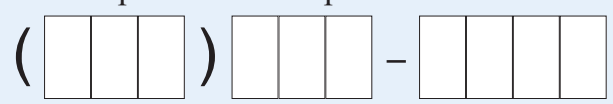

11-12. Your driver's license number and state (if any) 11. LICENSE
NUMBER

(

WE WILL USE THIS E-MAIL ADDRESS TO CORRESPOND WITH YOU. YOU WILL RECEIVE YOUR FAFSA INFORMATION THROUGH A SECURE LINK ON THE

$\begin{array}{ll}\text { 13. Your e-mail address } & \text { WE WILL USE THIS E-MAIL ADDRESS TO CORRESPOND WITH YOU. YOU WILL RECEIVE YOUR FAFSA INFORMATION THROUGH A SECURE LINK ON THE } \\ \text { INTERNET, SENT TO THE E-MALL ADDRESS YOU PROVIDE. LEAVE BLANK TO RECEIVE INFORMATION THROUGH REGULAR MAIL. WE WILL ONLY SHARE } \\ \text { THIS ADDRESS WITH THE SCHOOLS YOU LIST ON THE FORM AND YOUR STATE. THEY MAY USE THE E-MAIL ADDRESS TO COMMUNICATE WITH YOU. }\end{array}$

$\begin{array}{ll}\text { 13. Your e-mail address } & \text { WE WILL USE THIS E-MAIL ADDRESS TO CORRESPOND WITH YOU. YOU WILL RECEIVE YOUR FAFSA INFORMATION THROUGH A SECURE LINK ON THE } \\ \text { INTERNET, SENT TO THE E-MAIL ADDRESS YOU PROVIDE. LEAVE BLANK TO RECEIVE INFORMATION THROUGH REGULAR MALL. WE WILL ONLY SHARE } \\ \text { THIS ADDRESS WITH THE SCHOOLS YOU LIST ON THE FORM AND YOUR STATE. THEY MAY USE THE E-MAIL ADDRESS TO COMMUNICATE WITH YOU. }\end{array}$

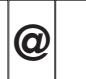

14. Are you a U.S. citizen? Pick one. See page 2.

a. Yes, I am a U.S. citizen. Skip to question 16.

b. No, but I am an eligible noncitizen. Fill in question 15 . . c. No, I am not a citizen or eligible noncitizen.
17. Month and year you were married, separated, divorced or widowed
15.

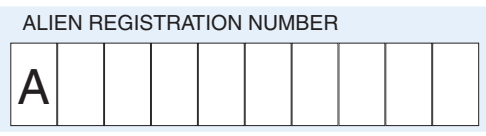

16. What is your marital status as of today?

I am separated

$\mathrm{O}^{2}$

19. Did you become a legal resident of this state before January 1, 2001?

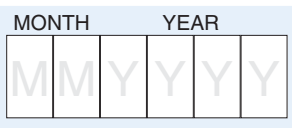

18. What is your state of legal residence?

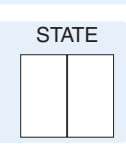

20. If the answer to question 19 is "No," give month and year you became a legal resident.

21. Are you male? (Most male students must register with Selective Service to get federal aid.)

22. If you are male (age 18-25) and not registered, answer "Yes" and Selective Service will register you.

24. What will be your grade level when you begin the 2006-2007 school year? See page 2 and enter the correct number in the box.

25. Will you have a high school diploma or GED before you begin the 2006-2007 school year?

26. Will you have your first bachelor's degree before July 1, 2006?

27. In addition to grants, are you interested in student loans (which you must pay back)?

28. In addition to grants, are you interested in "work-study" (which you earn through work)?

29. Highest school your father completed Middle school/Jr. High $\bigcirc 1$ High School $\bigcirc 2$

30. Highest school your mother completed Middle school/Jr. High $\bigcirc$ High School $\bigcirc 2$

College or beyond $\bigcirc_{3}$

$\begin{array}{lll}\text { Yes } \bigcirc_{1} & \text { No } & \bigcirc_{2} \\ \text { Yes } \bigcirc_{1} & \text { No } & \bigcirc_{2} \\ \text { Yes } \bigcirc_{1} & \text { No } & \bigcirc_{2} \\ \text { Yes } \bigcirc_{1} & \text { No } & { }_{2}\end{array}$

31. Do not leave this question blank. Have you ever been convicted of possessing or selling illegal drugs? If you have, answer "Yes," complete and submit this application, and we will send you a worksheet in the mail for you to determine if your conviction affects your eligibility for aid.

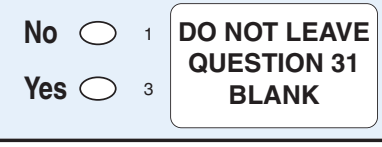

For Help - www.studentaid.ed.gov/completefafsa 

report your and your spouse's income and assets, even if you were not married in 2005. Ignore references to "spouse" if you are currently single, separated, divorced or widowed.

32. For 2005, have you (the student) completed your IRS income tax return or another tax return listed in question 33 ?
a. I have already completed my return.
b. I will file, but I have not yet completed my return.
c. I'm not going to file. (Skip to question 38.)

33. What income tax return did you file or will you file for 2005 ?
a. IRS 1040
b. IRS $1040 \mathrm{~A}$ or $1040 \mathrm{EZ}$
c. A foreign tax return. See page 2 .

d. A tax return with Puerto Rico, Guam, American Samoa, the U.S. Virgin Islands, the Marshall Islands, the Federated States of Micronesia, or Palau. See page 2.

34. If you have filed or will file a 1040, were you eligible to file a 1040A or 1040EZ? See page 2. For questions 35-47, if the answer is zero or the question does not apply to you, enter 0.

35. What was your (and spouse's) adjusted gross income for 2005? Adjusted gross income is on IRS Form 1040 - line 37; 1040A-line 21; or 1040EZ - line 4.

36. Enter your (and spouse's) income tax for 2005. Income tax amount is on IRS Form 1040-line 57; 1040A — line 36; or 1040EZ - line 10.

37. Enter your (and spouse's) exemptions for 2005. Exemptions are on IRS Form 1040-line 6d or on Form 1040A - line 6d. For Form 1040EZ, see page 2.

38-39. How much did you (and spouse) earn from working (wages, salaries, tips, combat pay, etc.) in 2005? Answer this question whether or not you filed a tax return. This information may be on your W-2 forms, or on IRS Form 1040-lines $7+12+$ 18; 1040A-line 7; or 1040EZ - line 1 .

Your Spouse (39) Student (and Spouse) Worksheets (40-42)

40-42. Go to page 8 and complete the columns on the left of Worksheets A, B, Worksheet A (40) and C. Enter the student (and spouse) totals in questions 40, 41 and 42, respectively. Even though you may have few of the Worksheet items, check each line carefully.

Worksheet B (41)

Worksheet C (42)

43. As of today, what is your (and spouse's) total current balance of cash, savings, and checking accounts? Do not include student financial aid.

44. As of today, what is the net worth of your (and spouse's) investments, including real estate (not your home)? Net worth means current value minus debt. See page 2.

45. As of today, what is the net worth of your (and spouse's) current businesses and/or investment farms? Do not include a farm that you live on and operate. See page 2.

46-47. If you receive veterans' education benefits, for how many months from July 1 , 2006, through June 30, 2007, will you receive these benefits, and what amount will you receive per month? Do not include your spouse's veterans' education benefits.

\section{Step Three: Answer all seven questions in this step.}

48. Were you born before January 1,1983 ? . . . . . . . . . . . . . . . . . . . . . . .

49. At the beginning of the 2006-2007 school year, will you be working on a master's or doctorate program (such as an MA, MBA, MD, JD, PhD, EdD, or graduate certificate, etc.)? ..................

50. As of today, are you married? (Answer "Yes" if you are separated but not divorced.) . . . . . . . . . . .

51. Do you have children who receive more than half of their support from you? . . . . . . . . . . . .

52. Do you have dependents (other than your children or spouse) who live with you and who receive more than half of their support from you, now and through June 30,2007 . . . . . . . . . . . . . .

53. Are (a) both of your parents deceased, or (b) are you (or were you until age 18) a ward/dependent of

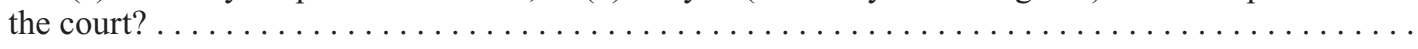

54. Are you a veteran of the U.S. Armed Forces? See page 2.

Yes
$\$ \$$

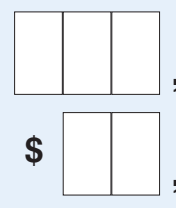

Don't Know

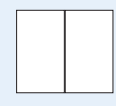

$\$$

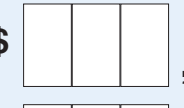

$\$$

\section{$\$$}

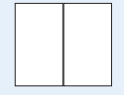

$\$$

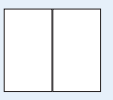

$\$$

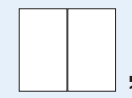

$\$$
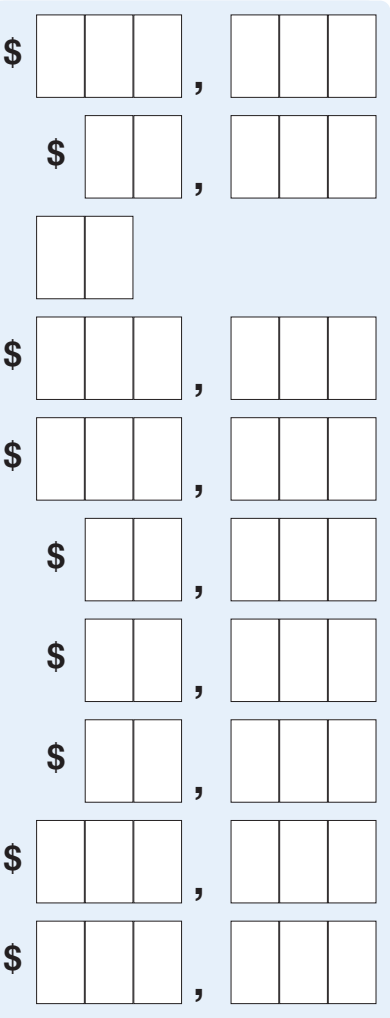

,

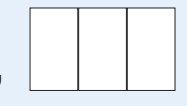

$\$$
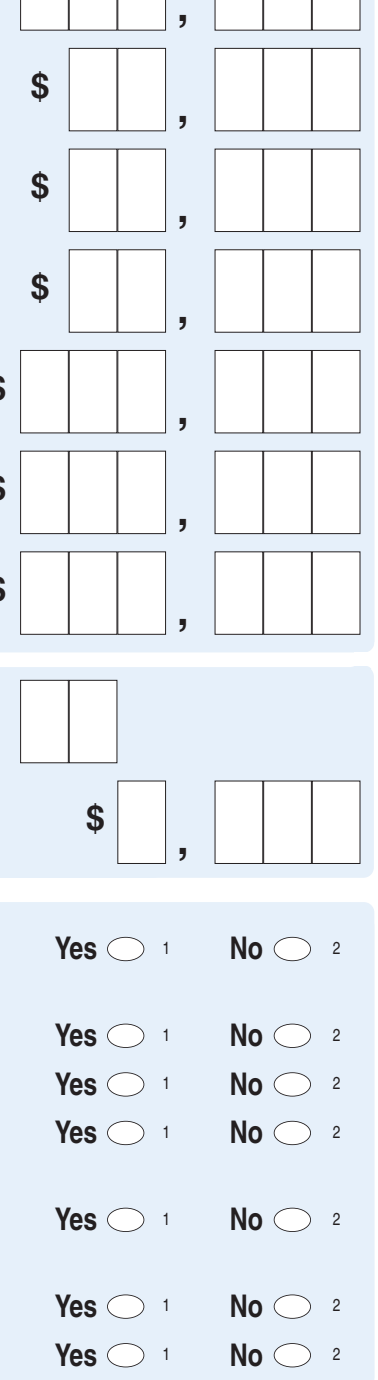

If you (the student) answered "No" to every question in Step Three, go to Step Four.

If you answered "Yes" to any question in Step Three, skip Step Four and go to Step Five on page 6.

(Health Profession Students: Your school may require you to complete Step Four even if you answered "Yes" to any Step Three question.) 
55. What is your parents' marital status as of today?

Married/Remarried

Single
56. Month and year they were married, separated, divorced or widowed

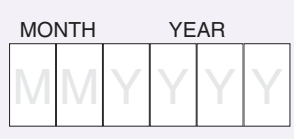

57-64. What are the Social Security Numbers, names and dates of birth of the parents reporting information on this form? If your parent does not have a Social Security Number, you must enter 000-00-0000.

57. FATHER'S/STEPFATHER'S SOCIAL SECURITY NUMBER

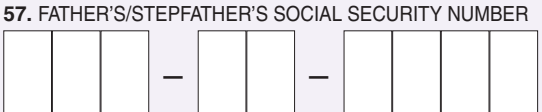

61. MOTHER'S/STEPMOTHER'S SOCIAL SECURITY NUMBER

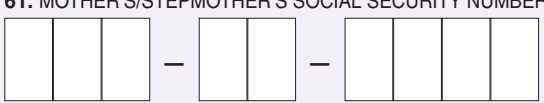

65. Go to page 7 to determine how many people are in your parents' household. Enter that number here.

58. FATHER'S/STEPFATHER'S LAST NAME, AND

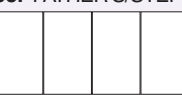

62. MOTHER'S/STEPMOTHER'S LAST NAME, AND

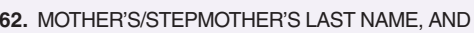

59. FIRST INITIAL

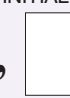

63. FIRST INITIAL
60. FATHER'S/STEPFATHER'S DATE OF BIRTH

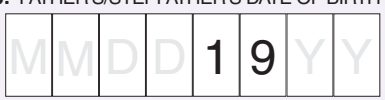

64. MOTHER'S/STEPMOTHER'S DATE OF BIRTH

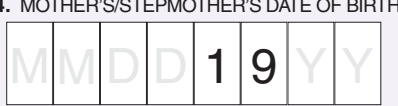

66. Go to page 7 to determine how many in question 65 (exclude your parents) will be college students between July 1, 2006, and June 30, 2007. Enter that number here.

67. What is your parents' state of legal residence?

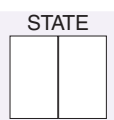

68. Did your parents become legal residents of this state before January 1, 2001?

69. If the answer to question 68 is "No," give month and year legal residency began for the parent who has lived in the state the longest.

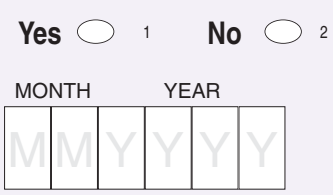

70. For 2005, have your parents completed their IRS income tax return or another tax return listed in question 71 ?
a. My parents have already completed their return.
b. My parents will file, but they have not yet completed their return.
c. My parents are not going to file. (Skip to question 76.)

71. What income tax return did your parents file or will they file for 2005 ?
a. IRS 1040
d. A tax return with Puerto Rico, Guam, American Samoa, the U.S. Virgin
b. IRS $1040 \mathrm{~A}$ or $1040 \mathrm{EZ}$
c. A foreign tax return. See page 2. Islands, the Marshall Islands, the Federated States of Micronesia, or Palau. See page 2.

72. If your parents have filed or will file a 1040, were they eligible to file a 1040A or 1040EZ? See page 2.

Yes No Don't Know $\bigcirc_{1} \bigcirc_{2} \bigcirc_{3}$

For questions 73-83, if the answer is zero or the question does not apply, enter 0.

73. What was your parents' adjusted gross income for 2005? Adjusted gross income is on IRS Form 1040 - line 37; 1040A - line 21; or 1040EZ - line 4.

74. Enter your parents' income tax for 2005. Income tax amount is on IRS Form 1040-line 57; 1040A - line 36; or 1040EZ - line 10.

75. Enter your parents' exemptions for 2005. Exemptions are on IRS Form 1040-line 6d or on Form 1040A—line 6d. For Form 1040EZ, see page 2.

76-77. How much did your parents earn from working (wages, salaries, tips, combat pay, etc.) in 2005? Answer this question whether or not your parents filed a tax return. This information may be on their W-2 forms, or on IRS Form 1040-lines $7+12+18 ; 1040 \mathrm{~A}$ - line 7 ; or 1040EZ-line 1 .

\section{Parent Worksheets (78-80)}

78-80. Go to page 8 and complete the columns on the right of Worksheets A, B, and C. Enter the parents' totals in questions 78,79 and 80 , respectively. Even though your parents may have few of the Worksheet items, check each line carefully.

Fatherl Stepfather (76)

Motherl

Stepmother (77)

Worksheet A (78)

Worksheet B (79)

Worksheet C (80)

81. As of today, what is your parents' total current balance of cash, savings, and checking accounts?

82. As of today, what is the net worth of your parents' investments, including real estate (not your parents' home)? Net worth means current value minus debt. See page 2.

83. As of today, what is the net worth of your parents' current businesses and/or investment farms? Do not include a farm that your parents live on and operate. See page 2.
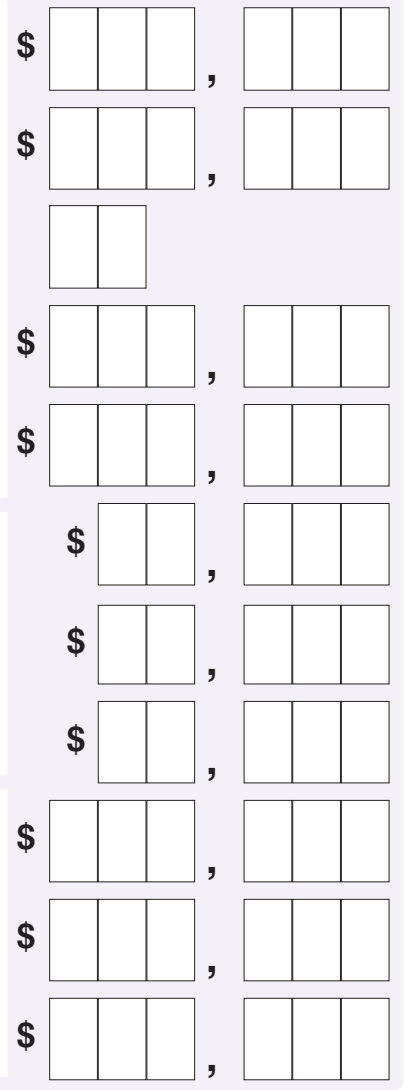

\section{Page 5}

For Help - www.studentaid.ed.gov/completefafsa 
Step Five: Complete this step only if you (the student) answered "Yes" to any Step Three question.

84. Go to page 7 to determine how many people are in your (and your spouse's) household. Enter that number here.
85. Go to page 7 to determine how many people in question 84 will be college students, attending at least half time between July 1, 2006, and June 30, 2007. Enter that number here.

\section{Step Six: Please tell us which schools may request your information, and indicate your enrollment status.}

Enter the 6-digit federal school code and your housing plans. Look for the federal school codes at www.fafsa.ed.gov, at your college financial aid office, at your public library, or by asking your high school guidance counselor. If you cannot get the federal school code, write in the complete name, address, city and state of the college. For state aid, you may wish to list your preferred school first.

86.
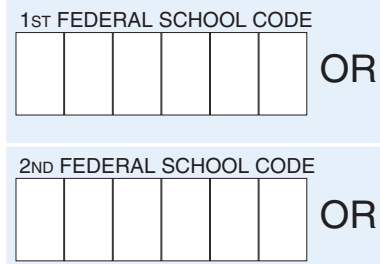

90.

3RD FEDERAL SCHOOL CODE

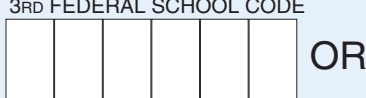

92.

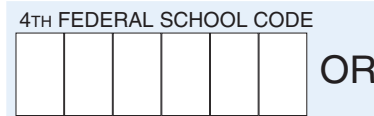

94.

5TH FEDERAL SCHOOL CODE

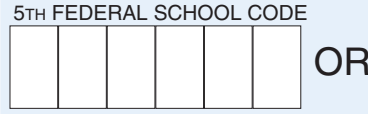

96.

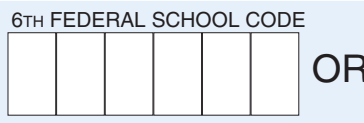

\begin{tabular}{ll|} 
NAME OF \\
COLLEGE & \\
ADDRESS & \\
AND CITY & \\
NAME OF & \\
COLLEGE & \\
ADDRESS & \\
AND CITY & \\
NAME OF & \\
COLLEGE & \\
ADDRESS & \\
AND CITY & \\
NAME OF & \\
COLLEGE & \\
ADDRESS & \\
AND CITY & \\
NAME OF & \\
COLLEGE & \\
ADDRESS \\
AND CITY \\
NAME OF \\
COLLEGE \\
ADDRESS \\
AND CITY
\end{tabular}

STATE

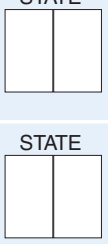

STATE
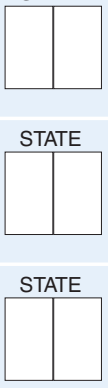

STATE

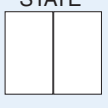

HOUSING PLANS

87. on campus off campus with parent on campus

89. off campus with parent on campus

91. off campus with parent on campus

93. off campus with parent on campus

95. off campus with parent on campus

97. off campus with parent

98. See page 7. At the start of the 2006-2007 school year, mark if you will be:

Full
time ${ }_{1} \quad \begin{gathered}3 / 4 \\ \text { time }\end{gathered} \bigcirc{ }_{2} \quad \begin{gathered}\text { Half } \\ \text { time }\end{gathered} \bigcirc 3 \begin{gathered}\text { Less than } \\ \text { half time }\end{gathered}$

\section{Step Seven: Read, sign and date.}

If you are the student, by signing this application you certify that you (1) will use federal and/or state student financial aid only to pay the cost of attending an institution of higher education, (2) are not in default on a federal student loan or have made satisfactory arrangements to repay it, (3) do not owe money back on a federal student grant or have made satisfactory arrangements to repay it, (4) will notify your school if you default on a federal student loan and (5) will not receive a Federal Pell Grant for more than one school for the same period of time.

If you are the parent or the student, by signing this application you agree, if asked, to provide information that will verify the accuracy of your completed form. This information may include U.S. or state income tax forms that you filed or are required to file. Also, you certify that you understand that the Secretary of Education has the authority to verify information reported on this application with the Internal Revenue Service and other federal agencies. If you sign any document related to the federal student aid programs electronically using a Personal Identification Number (PIN), you certify that you are the person identified by the PIN and have not disclosed that PIN to anyone else. If you purposely give false or misleading information, you may be fined $\$ 20,000$, sent to prison, or both.
If this form was filled out by someone other than you, your spouse or your parents, that person must complete this part.

Preparer's name, firm and address
101. Preparer's Social Security Number (or 102)

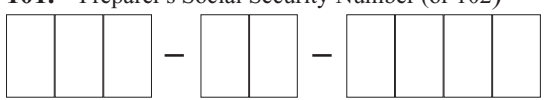

102. Employer ID number (or 101)

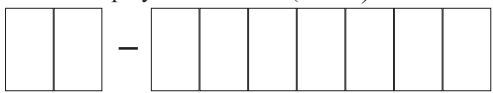

103. Preparer's signature and date
99. Date this form was completed.

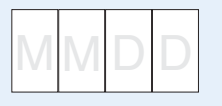

2006

or

2007
100. Student (Sign below)

Parent (A parent from Step Four sign below) 
Read these notes to determine who is considered a parent on this form. Answer all questions in Step Four about them, even if you do not live with them. (Note that grandparents, foster parents and legal guardians are not parents.)

If your parents are living and married to each other, answer the questions about them.

If your parent is widowed or single, answer the questions about that parent. If your widowed parent is remarried as of today, answer the questions about that parent and the person whom your parent married (your stepparent).

If your parents are divorced or separated, answer the questions about the parent you lived with more during the past 12 months. (If you did not live with one parent more than the other, give answers about the parent who provided more financial support during the past 12 months, or during the most recent year that you actually received support from a parent.) If this parent is remarried as of today, answer the questions on the rest of this form about that parent and the person whom your parent married (your stepparent).

\section{Notes for question 65 (page 5)}

Include in your parents' household (see notes, above, for who is considered a parent):

- your parents and yourself, even if you don't live with your parents,

- your parents' other children if (a) your parents will provide more than half of their support from July 1, 2006, through June 30, 2007, or (b) the children could answer "no" to every question in Step Three on page 4 of this form, and

- other people if they now live with your parents, your parents provide more than half of their support, and your parents will continue to provide more than half of their support from July 1, 2006, through June 30, 2007.

\section{Notes for questions 66 (page 5) and 85 (page 6)}

Always count yourself as a college student. Do not include your parents. Include others only if they will attend, at least half time in 2006-2007, a program that leads to a college degree or certificate.

\section{Notes for question 84 (page 6)}

Include in your (and your spouse's) household:

- yourself (and your spouse, if you have one),

- your children, if you will provide more than half of their support from July 1, 2006, through June 30, 2007, and

- other people if they now live with you, you provide more than half of their support, and you will continue to provide more than half of their support from July 1, 2006, through June 30, 2007.

\section{Notes for question 98 (page 6)}

For undergraduates, "full time" generally means taking at least 12 credit hours in a term or 24 clock hours per week. "3/4 time" generally means taking at least 9 credit hours in a term or 18 clock hours per week. "Half time" generally means taking at least 6 credit hours in a term or 12 clock hours per week. Provide this information about the college you are most likely to attend.

\section{Information on the Privacy Act and use of your Social Security Number}

We use the information that you provide on this form to determine if you are eligible to receive federal student financial aid and the amount that you are eligible to receive. Sections 483 and 484 of the Higher Education Act of 1965, as amended, give us the authority to ask you and your parents these questions, and to collect the Social Security Numbers of you and your parents. We use your Social Security Number to verify your identity and retrieve your records, and we may request your Social Security Number again for those purposes.

State and institutional student financial aid programs may also use the information that you provide on this form to determine if you are eligible to receive state and institutional aid and the need that you have for such aid. Therefore, we will disclose the information that you provide on this form to each institution you list in questions $86-96$, state agencies in your state of legal residence, and the state agencies of the states in which the colleges that you list in questions 86-96 are located.

If you are applying solely for federal aid, you must answer all of the following questions that apply to you: $1-9,14-16,18,21-22,25-26,31-36,38-45,48-67,70-74$, 76-85 and 99-100. If you do not answer these questions, you will not receive federal aid.

Without your consent, we may disclose information that you provide to entities under a published "routine use." Under such a routine use, we may disclose information to third parties that we have authorized to assist us in administering the above programs; to other federal agencies under computer matching programs, such as those with the Internal Revenue Service, Social Security Administration, Selective Service System, Department of Homeland Security, Department of Justice and Veterans Affairs; to your parents or spouse; and to members of Congress if you ask them to help you with student aid questions.

If the federal government, the U.S. Department of Education, or an employee of the U.S. Department of Education is involved in litigation, we may send information to the Department of Justice, or a court or adjudicative body, if the disclosure is related to financial aid and certain conditions are met. In addition, we may send your information to a foreign, federal, state, or local enforcement agency if the information that you submitted indicates a violation or potential violation of law, for which that agency has jurisdiction for investigation or prosecution. Finally, we may send information regarding a claim that is determined to be valid and overdue to a consumer reporting agency. This information includes identifiers from the record; the amount, status and history of the claim; and the program under which the claim arose.

\section{State Certification}

By submitting this application, you are giving your state financial aid agency permission to verify any statement on this form and to obtain income tax information for all persons required to report income on this form.

\section{The Paperwork Reduction Act of 1995}

The Paperwork Reduction Act of 1995 says that no one is required to respond to a collection of information unless it displays a valid OMB control number, which for this form is 1845-0001. The time required to complete this form is estimated to be one hour, including time to review instructions, search data resources, gather the data needed, and complete and review the information collection. If you have comments about this estimate or suggestions for improving this form, please write to: U.S. Department of Education, Washington DC 20202-4700.

We may request additional information from you to process your application more efficiently. We will collect this additional information only as needed and on a voluntary basis. 


\section{Calendar Year 2005}

Student/Spouse

For question 40

$\$$

$\$$

$\$$

$\$$

$\$$

$\$$

$\$$

$\$$

$\$$

$\$$

$\$$

$\$$

$\$$

$\$$

$\$$

$\$$

$\$$

$\$$

For question 42

$\$$

$\$$

$\$$

$\$$

1040A - line 31
Do not mail these worksheets in with your application.

Keep these worksheets; your school may ask to see them.

Worksheet A

Report Annual Amounts
Parents

For question 78

$\$$

$\$$

food stamps or subsidized housing.

Social Security benefits received, for all household members as reported in question 84 (or 65

for your parents), that were not taxed (such as SSI). Report benefits paid to parents in the

Parents column, and benefits paid directly to student (or spouse) in the Student/Spouse column.

$\$$

Enter in question 40.

Enter in question 78. — $\$$

\section{Worksheet B}

\section{Report Annual Amounts}

Payments to tax-deferred pension and savings plans (paid directly or withheld from earnings), including, but not limited to, amounts reported on the W-2 Form in Boxes 12a through 12d, codes D, E, F, G, H and S

IRA deductions and payments to self-employed SEP, SIMPLE, and Keogh and other qualified plans from IRS Form 1040-line 28 + line 32 or 1040A-line 17

For question 79

$\$$

Child support you received for all children. Don't include foster care or adoption payments.

Tax exempt interest income from IRS Form 1040 - line 8b or 1040A-line 8b

Foreign income exclusion from IRS Form 2555-line 43 or 2555EZ-line 18

$\$$

$\$$

$\$$

$\$$

Untaxed portions of IRA distributions from IRS Form 1040-lines (15a minus 15b) or

$1040 \mathrm{~A}$ - lines (11a minus 11b). Exclude rollovers. If negative, enter a zero here.

$\$$

Untaxed portions of pensions from IRS Form 1040 - lines (16a minus 16b) or 1040A—lines

(12a minus 12b). Exclude rollovers. If negative, enter a zero here.

Credit for federal tax on special fuels from IRS Form 4136-line 15 (nonfarmers only)

$\$$

Housing, food and other living allowances paid to members of the military, clergy and others

(including cash payments and cash value of benefits)

$\$$

Veterans' noneducation benefits such as Disability, Death Pension, or Dependency \& Indemnity

Compensation (DIC), and/or VA Educational Work-Study allowances

$\$$

Other untaxed income not reported elsewhere on Worksheets A and B (e.g., workers'

compensation, untaxed portions of railroad retirement benefits, Black Lung Benefits, disability,

combat pay not reported on the tax return, etc.)

Don't include student aid, Workforce Investment Act educational benefits, non-tax filers'

combat pay, or benefits from flexible spending arrangements, e.g., cafeteria plans.

$\$$

Money received, or paid on your behalf (e.g., bills), not reported elsewhere on this form

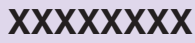

Enter in question 41.

Enter in question 79. — \$

\section{Worksheet C}

\section{Report Annual Amounts}

Education credits (Hope and Lifetime Learning tax credits) from IRS Form 1040-line 50 or

Child support you paid because of divorce or separation or as a result of a legal requirement.

Don't include support for children in your (or your parents') household, as reported in question

\begin{tabular}{ll}
84 (or question 65 for your parents). \\
\hline
\end{tabular} need-based employment portions of fellowships and assistantships

Student grant and scholarship aid reported to the IRS in your (or your parents') adjusted gross

income. Includes AmeriCorps benefits (awards, living allowances and interest accrual

payments), as well as grant or scholarship portions of fellowships and assistantships. 